\title{
The Metallurgy of the Sicilian Final Bronze Age/Early Iron Age necropolis of Madonna del Piano (Catania, Sicily)
}

\author{
La metalurgia de la necrópolis siciliana del Bronce Final/Primera Edad del Hierro de \\ Madonna del Piano (Catania, Sicilia)
}

\author{
Alessandra Giumlia-Mair (*) \\ Rosa Maria Albanese Procelli (**) \\ Fulvia Lo Schiavo $(* * *)$
}

\begin{abstract}
This paper presents the analysis results of the copper-based finds, from the important Sicilian necropolis of Madonna del Piano, near Grammichele (Catania), dated between the local Final Bronze Age 2 and the Early Iron Age IA. 122 copper-based finds from the 273 graves (1970-71) of the large cemetery have been analysed.

The sampled objects belong to different classes, there are for instance weapons of offence and defence, such as swords and greaves, small decorative objects for personal use, such as rings, fibulae, belt hooks, belt decorations, and small tools, such as the knives used by women, reels, needles and razors, but also small functional parts, such as rivets and nails, repairs and even a kind of musical instrument, such as the tintinnabula.

The methods employed were AAS and SEM, where possible, and XRF in all cases.

The aim of the research was that of evaluating the skill of the local artisans, of determining the most common copper-based alloys in use in Sicily in this period and comparing the data with the analysis results of contemporary groups of finds from other areas of the Italian peninsula and from other European regions.
\end{abstract}

\section{RESUMEN}

El artículo presenta el resultado de los análisis realizados a los metales de base cobre de la importante necrópolis siciliana de Madonna del Piano, próxima a Grammichele (Catania), fechada entre el Bronce Final 2

(*) AGM Archeoanalisi, via E.Toti 8, I-39012 Merano (BZ), Italy. Correo electrónico: giumlia@yahoo.it

(**) Università di Catania, Dipartimento di Studi Archeologici, Filologici e Storici (SAFiSt) della Facoltà di Lettere e Filosofia, Catania, Italy. Correo electrónico: albaros@unict.it y la Primera Edad del Hierro IA. Se han estudiado un total de 122 objetos de base cobre procedentes de 273 tumbas excavadas entre 1970 y 1971.

Los objetos muestreados pertenecen a diferentes tipos, armas ofensivas y defensivas tales como espadas y grebas, pequeños objetos de uso personal como anillos, fibulas, broches de cinturón y pequeñas herramientas como cuchillos usados por las mujeres, carretes, agujas, navajas, pero también elementos funcionales como remaches, clavos y un tipo de instrumento como el tintinábulo.

Los métodos de análisis utilizados fueron AAS y SEM, cuando fue posible y XRF para todos los casos. El objetivo de esta investigación es evaluar la habilidad de los artesanos locales y determinar el tipo de aleación más común en Sicilia durante este periodo, comparando los datos con los resultados obtenidos en grupos de hallazgos contemporáneos de otras partes de la península italiana y otras regiones europeas.

Key words: Final Bronze Age; Early Iron Age; Necropolis; Copper-based finds; Sicily; Madonna del Piano; AAS; XRF; SEM.

Palabras clave: Bronce Final; Primera Edad del Hierro; Necrópolis; Objetos de base cobre; Sicilia; Madonna del Piano; AAS; XRF; SEM.

\section{SITE AND MATERIALS (Rosa Maria Albanese Procelli)}

In 1970 and 1971 two excavations were carried out in the necropolis of Madonna del Piano,

$(* * *)$ Soprintendenza per i Beni Archeologici della Toscana, Via della Pergola 65, I-50121 Firenze, Italy. Correo electronico: fulvia.loschiavo@beniculturali.it

Recibido: 16-III-2010; aceptado: 26-III-2010. 
near Grammichele (Catania, Eastern Sicily) (Fig. 1). In this occasion 273 graves were brought to light (Albanese Procelli 1992, 1994, 2003; Albanese Procelli, La Piana: forthcoming). Previously, in 1889, 14 graves had been excavated by Paolo Orsi in the nearby site of Mulino della Badia (Orsi 1905). In 1959 further 47 graves had been discovered in Madonna del Piano (Bernabò Brea, Militello, La Piana 1969). The funerary gifts of 12 more graves were recovered in 1974.

The 1970-1971 excavations brought to light 844 copper-based grave gifts, 10 of which were composite objects (tintinnabula pectorals). 122 analyses were performed on around 75 objects (5 are sporadical finds). Different classes of objects were selected: decorative objects of personal use, weapons, tools and utensils. The largest group is that of the fibulae, with 206 specimens.

The wheel-shaped decorations, which, because of the position in the graves and the comparisons with Southern Italian funerary contexts, can be defined belt decorations, are typical of female burials. These have been found in ten of the graves. The specimens with the inv. n. 71209 from the grave 211 and inv. n. 71363 from the grave 255 have been analysed.

The so-called tintinnabula pectorals are particularly complex ornaments which belonged to few women who played a special role in the local community. Of these, the examples from the graves 197 and 255 have been analysed. These objects were most probably worn as pectorals

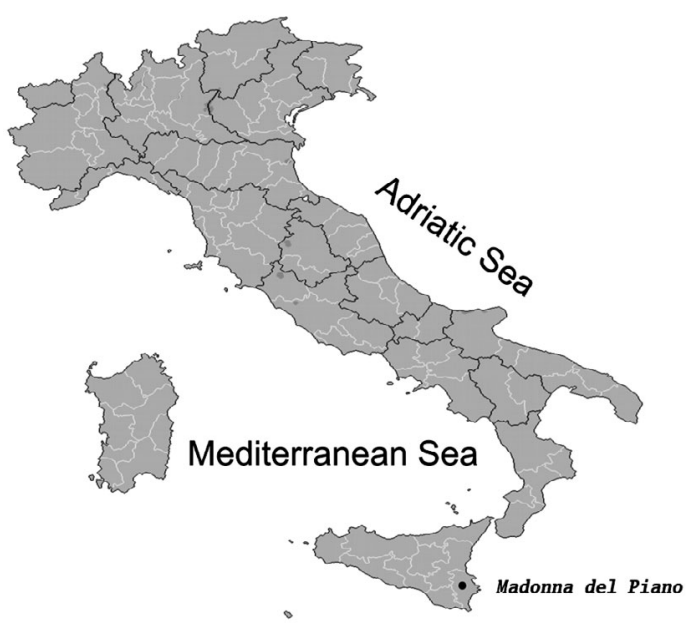

Fig. 1. The map shows the location of the site of Madonna del Piano in Sicily. hanging from a bronze chain (as more complete finds show, see Bernabò Brea, Militello, La Piana 1969, Fig. 14, t. 5/1959) and tinkled whenever the person wearing them moved.

In grave 197 a zoomorphic pendant, of a kind documented also in three more graves (150 bis, 209, 251) was found under a fibula and perhaps it was hanging from it. Zoomorphic pendants in the shape of bovides or small bulls were found together with tintinnabulum pectorals in the graves 150bis, 197 and 251, but not in grave 209, therefore the connection between the two items cannot be confirmed (Fig. 2).

In the necropolis 4 plate-shaped belt hooks have been found in male burials, however the analysed example inv. n. 71354 from grave 253

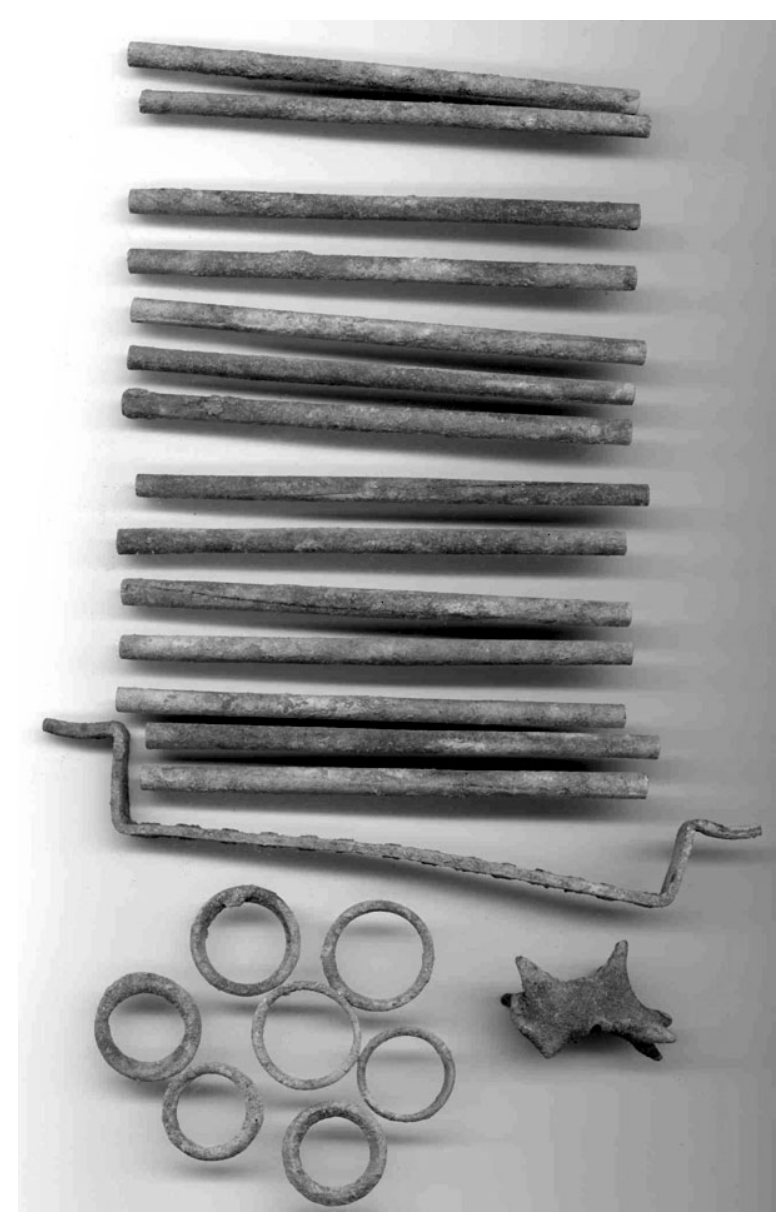

Fig. 2. Tintinnabulum from grave 197, tubuli, perforated bar, rings and perforated calf figurine. NotaBene, on this photo the tubuli are arranged in the wrong direction. They hanged vertically from the bar. 
was found with a knife and this fact might indicate that it was buried in a woman's grave.

Only four of the male depositions contain weapons, 2 with a sword of Contigliano type (graves 26 and 40) and one of Allerona type (grave 194) (Albanese Procelli 1994; Albanese Procelli, Lo Schiavo 2004). Both types have parallels in Southern Italy. Only the warrior in grave 26 had a set of offensive and defensive weapons. To this grave belongs the only pair of greaves found up to now in the necropolis (and in Sicily). This type has Aegaean prototypes and there are close parallels in Calabria and Campania (Albanese Procelli 1994).

Except for the greaves the only further objects in the necropolis which show a repoussé decoration are some sheet metal discs with a central perforation.

Razors are present in 16 male burials. Of these 3 examples from graves 11, 194 and 195 have been analysed.

Knives with a one sided cutting blade seem to belong exclusively to female depositions. Their position in the graves seems to indicate that they were hanging from the belt. Over 60 specimens have been recovered and among the analysed pieces there were the knives inv. nos. 70589 from grave 7 (enchytrismos burial, Fig. 3) and 70577 from grave 4 (pit burial) which are of especially accurate manufacture. However the set of funerary gifts found in the two graves are common finds (fibula, finger ring, needle, jug and spindle in grave 4; fibula, finger ring and jug in grave 7). The remaining knives inv. nos. 71353, 71362 and 71208 come from the graves 253,255 and 211 respectively. Graves 255 and 211 have a more complex set of burial gifts. For example in grave 255 there are 4 bronze objects, a tintinnabulum pectoral and a glass paste bead, while in grave 211 there are 5 bronze objects, vessels and an amber bead. The interpretation of the knife from grave

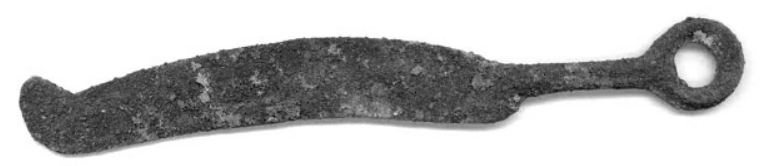

Fig. 3. Knife (inv. n. 70589) of good quality from grave 7. L.: ca. $19 \mathrm{~cm}$.

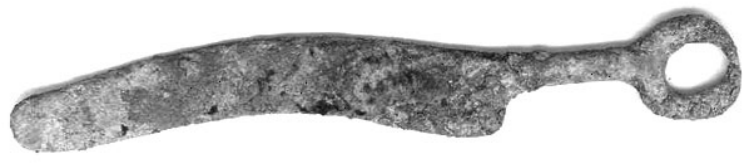

Fig. 4. Miniaturised knife (inv. n. 71185) from grave 207. The tool has an awkward, not very functional shape. Perhaps it is a broken and readapted blade. L.: ca. $12 \mathrm{~cm}$.

207 (Fig. 4) which shows traces of wear but was shown by the analyses to be less functional than other examples, is quite problematic, as the type of grave (a $1.58 \mathrm{~m}$ long pit) and the grave gifts - an elbow fibula of serpeggiante type, a finger ring, an ivory comb and a distaff made of bone are not compatible with a child burial.

In other cases, and in particular in the case of enchytrismos burials there are funerary gifts which, because of their dimensions and typology, can be possibly interpreted as objects for children's burials. Of these there are examples which show a high level of complexity and indicate that their social standing was established at birth. The grave 260 with enchytrismos burial is that of a child and it contains anklets (inv. n. 71377) and a miniature fibula (inv. n. 71375).

The rods with perforated ends - interpreted as reels - and needles are connected with female working activities.

Metallurgical analyses allow important observations on the production technology and - with due caution, because of the still limited statistical basis - also some hypotheses on everyday life habits and on the funerary rituals. The latter show a great variability, both in the burial procedures - such as for example trench burials, enchytrismos burials and cremation - and in the large number of combinations in the set of burial gifts, with quantitative (between one and 16 objects) and qualitative differences, and give us an idea of the complex social organisation structure, divided into classes according to age, of the local community.

\section{THE ANALYTICAL PROJECT (Alessandra Giumlia-Mair)}

This project was initiated, because of the importance of the necropolis and to obtain analytical data on the metallurgy of Sicily, but also be- 
cause previous analyses of materials from the Sicilian site of Modica and from the chronologically comparable sites, such as Pertosa, Cuma and Noepolis - all in the Pigorini Museum in Rome - had given interesting results concerning the production technology of some of the fibulae (Lo Schiavo et al. 2002; Giumlia-Mair, Lo Schiavo 2002). The analyses evidenced clear differences in the composition of the alloys employed for the different parts of some thickened bow- and elbow fibulae.

The results seemed to suggest that in Sicily leaded bronze alloys had been employed for cast on parts of fibulae as early as in the Late Bronze Age. On the other hand the analyses of materials from other Italian regions and from the area around the Eastern Alps had shown that leaded alloys, correlated with the function of the objects and with the production technology, had been introduced in the local metallurgy only at the beginning of the full Iron Age (Giumlia-Mair 1995; 1998 a; b, c; 2000, 2005b). Therefore a further important result of the analyses of the materials from Madonna del Piano was that of obtaining data which could be compared to that of the analyses of the fibulae from Modica, Pertosa, Cuma and Noepolis and confirm the use of leaded alloys also in this Sicilian area.

\section{METHODS OF ANALYSIS}

To be able to collect the maximum number of data and to obtain a preliminary screening of all selected objects it was decided to use X-rays spectrometry (XRF) on all metal finds. Wherever it was possible to obtain samples from metallic objects atomic absorption spectrometry (AAS) was also used. Corroded items were not selected for analysis and sampled.

Particularly interesting fragments, such as the fragments from the tubuli of the tintinnabula, but also small fragments of the organic material from the handle of the knives, were also examined and, in the case of metal, analysed in the scanning electron microscope (SEM/EDS) before the dissolution for the AAS analysis. The results have a precision of approx. $\pm 1-2 \%$ for $\mathrm{Cu}, \pm 5 \%$ for elements present at a level greater than $1 \%$, but decreasing to $\pm 50 \%$ at the respective detection limits.
Before the XRF analysis and before sampling, all objects were examined with various optical magnification devices to determine the conservation conditions of each piece and to find the best area for sampling. Objects which were too corroded for analysis were discarded from the selection. The selected items belong to different classes and are of different usage: among the most important groups there are small decorative objects of personal use - such as fibulae, rings, anklets, pins and belt hooks-tools, such as needles, knives, razors and tools for reeling thread -, weapons - such as swords and greaves -, and important ritual items such as the interesting tintinnabula.

In the case of complex objects all different parts, also small mechanical parts, such as rivets and nails, were analysed.

\section{DISCUSSION OF RESULTS}

The analyses (see Table of results and Fig. 5) have shown that the average tin content in all objects analysed is around 9\%, however the range is $4-14 \%$ (standard deviation 2,9), even if outliers, such as the belt decorations and tintinnabula, which contain higher tin percentages than the average, have not been taken into account in this calculation.

The highest tin contents were determined in the wheel-shaped belt decorations with up to

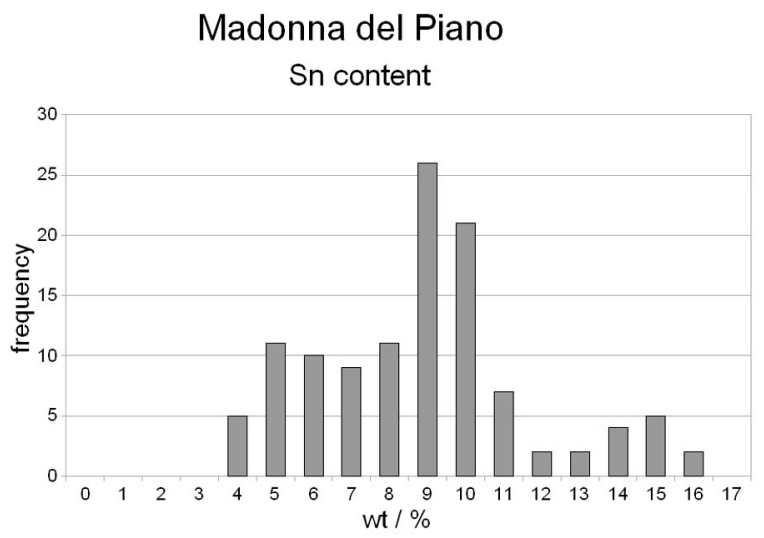

Fig. 5. The histogram shows the overall tin content of the analysed objects. The average is around $9 \%$, but the range is $4-14 \%$. The items with Sn contents over $11 \%$ are the tintinnabula and the wheel-shaped belt elements. The items with Sn contens under $7 \%$ are mainly everyday objects and tools. 
$17 \%$ of tin. The objects with the lowest tin content are the knives found in the graves of women, the tools for reeling thread and the razors, but there are also other items, for example miniature objects used as funerary gifts in children's graves (see below) which contain low tin percentages.

Only a few objects among those selected for analysis are made of unalloyed copper. These are a piece of thread, found in grave n. 15 together with a fibula, a decorative part of a sword sheath made of wood and the thin nails which were employed to fix it on the wood from grave n. 48. In this particular case it is clear, that the choice of having nails made of copper, on a decorative piece of copper applied to a prestigious object like the sheath of a sword, is due to the wish of having all details made of a metal of the same colour for aesthetic reasons, however in other cases copper alloys with low tin contents were employed for very minor items, such as rivets and similar mechanical parts.

The copper employed for the objects from the necropolis seems in general to be very pure, with very little trace elements and it would be compatible with the copper of the oxhide ingots found in Sicily at Cannatello and in Thapsos (Lo Schiavo et al. 2005; 2009; Giumlia-Mair 2009a). It is well known that the trace elements determined in the oxhide ingots from different sites all around the Mediterranean and in European contexts are always extremely low and the copper has a purity of over $98-99 \%$.

As mentioned in the introduction, the use of lead (Fig. 6) as a functional and deliberate alloy-

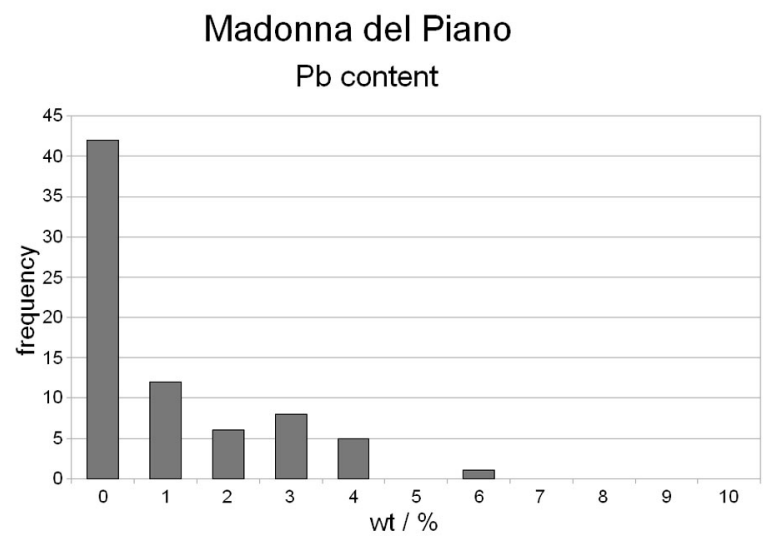

Fig. 6. The histogram shows the overall lead content of the analysed objects. Only very few objects contain more than $2 \%$ and most of them are fibulae. ing element, correlated with the production technology and the employment of the object is one of the most important points for this research and will be discussed below, in the section dedicated to the fibulae.

\section{WEAPONS}

The weapons recovered from the graves of Madonna del Piano are certainly some of the most representative and interesting pieces found in the necropolis.

The swords dated to this period which have been analysed in different contexts and in different regions of Europe and around the Mediterranean contain in average around $10 \%$ of tin and are among the most carefully prepared and accurately worked classes of objects. Also the examples of swords found at Madonna del Piano are carefully finished items and in excellent condition.

Two of the swords are of Contigliano type. However, while the one contains ca. $8 \% \mathrm{Sn}$ and some $\mathrm{Pb}$, the other - which also has a sheath with a point made of a good bronze, with a tin percentage of around $10 \%$ - surprisingly contains only $5.3 \%$ of tin. Both swords are in excellent condition and do not seem to have ever been used. This fact, together with the very low tin content of the second example, might suggest that these were ceremonial weapons, carried only in some special circumstances, or even that, at least the second sword, had been produced for funerary use only.

However an Agaean sword blade analysed by Craddock (1976: 102) and some examples found in the Ría de Huelva hoard and in other Iberian sites also have a similar composition (Rovira 1995; Rovira and Gómez 1998: 34-37), and, among the many swords from Greece, dated to the Late Bronze Age, analysed in the British Museum and with a tin average of $9.3 \%$, there are also some of lesser quality. Their tin content range goes from 6.8 to $12.4 \%$ (Craddock 1976: $101)$ and their composition can be compared with that of the the sword examples from Madonna del Piano.

The third sword found in the necropolis is of Allerona type and the alloy which was used for its production is a well purified copper with around $10 \%$ of tin, i.e. it is the most commonly employed alloy for swords. The third sword 
seems therefore to be an efficient weapon which has certainly been used by its owner.

The swords from the Iberian peninsula analysed by Rovira (1995) contain in average around $10 \%$ of tin and low percentages of lead. Their alloys are quite different from those employed for the swords analysed in the British islands and in France, which contain noticeably higher lead percentages, up to 5-7 \% (Rovira and Gómez 1998: 82 ). The Mediterranean tradition in the manufacture of swords seems to be homogeneous and quite distinct from the metallurgical tradition in Northern European countries, in particular because of the lead content.

Greaves of Aegean type (inv. n. 70630) have been found in grave 26 of the necropolis (Albanese Procelli 1994 and above). It is important to note that among the finds from the necropolis there are only very few objects made of sheet metal. The preferred production technique seems to have been casting with only limited hammering for finishing some parts of the items.

Except for the greaves, the only analysed sheet metal objects from the cemetery are a thin decorative disc (inv. n. 70751) and the tubuli belonging to the tintinnabula (see below). The greaves belong to a small group of objects worked by repoussè and their production technology is quite different from that of most of the other finds (which are mainly cast and sometimes slightly wrought). This more time consuming technology seems to indicate that these defensive weapons were a special and highly prized item. Between the composition of the metal used for the greaves and that of the other objects from the necropolis no difference can be distinguished, however this does not mean that the greaves must be of local production. As already mentioned the copper employed for the production of all objects from the necropolis of Madonna del Piano is pure, with only low trace elements, and the presence of oxhide ingots on the island seems to testify that at least part of the copper employed in Sicily came from Cyprus. This does not exclude the import of copper from other areas or even perhaps some most probably very limited - local extractive activity (which up to now has never been evidenced). The uniqueness of the greaves and of their production technology and decoration on the site of Madonna del Piano are therefore the only objective observation which can be expressed for the moment. However it should also be mentioned that similar items are known from the Italian peninsula, in particular from Calabria and Campania (see Albanese Procelli 1994 and above) and that they might have been imported from there.

\section{THE TYPOLOGY OF THE FIBULAE (Fulvia Lo Schiavo)}

The class of the fibulae is one of the most important in the necropolis and it deserves a detailed discussion. The following study is part of a larger research on the fibulae of Southern Italy and Sicily (Lo Schiavo forthcoming) which takes into consideration the examples from Molino della Badia (Orsi 1905) and those from Madonna del Piano published in 1969 (Bernabò Brea, La Piana, Militello 1969). Fibulae and weapons are the largest classes of objects found in protohistoric cemeteries in general, and in particular in Madonna del Piano. The study of these finds allows us to understand larger cultural phenomena and supports the historical reconstruction of the population and the region (Albanese Procelli, Lo Schiavo 2004; Lo Schiavo 2008). The multidisciplinary approach is the only one which concretely helps overcome the problems of a partial understanding of the objects and of their presence in different combinations in the set of burial gifts. The technical data are a significant element in the development of fashion, customs and rituals (Lo Schiavo 2003; Albanese Procelli, Lo Schiavo 2004; Lo Schiavo et al. 2009).

In the group of 23 fibulae (sampled each 1-4 times with a total of 43 analyses) 18 types can be recognized (10 bow fibulae and 8 of serpeggiante-type). Type 289 consists of 5 different varieties with 7 fibulae belonging to the same type. This is preliminary data, the entire study will be published in due time.

\section{Fibule ad arco (bow fibulae)}

The earliest analysed example is inv. n. 70792, a Fibula ad arco semplice con parte centrale appiattita e sottile costolatura centrale (Tipo 21 B, Fig. 7). This type is inhomogeneous, but typologically well characterized and parallel to the Castellace-type, produced in Ionian Calabria, 


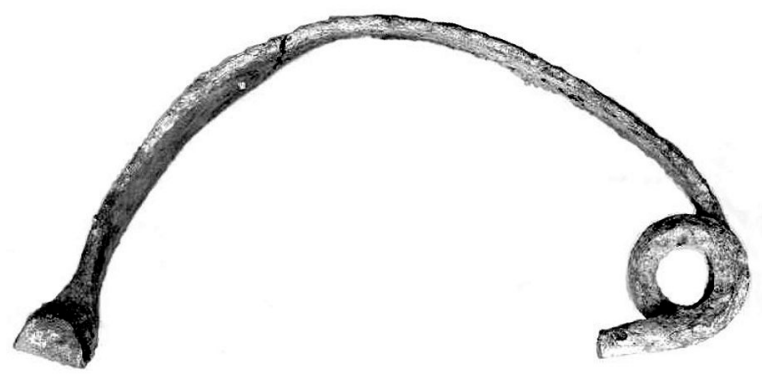

Fig. 7. Fibula ad arco semplice con parte centrale appiattita e sottile costolatura centrale, inv. n. 70792 (simple bow fibula with flattened central part and thin central rib). W.: 9,2 cm.

in the Locris area. It is documented in the Final Bronze Age 2, but was possibly also used later.

A Fibula ad arco ritorto (similar to type 27, n.70582) belongs to the same time and it is known from 3 sites in Eastern Sicily (Molino della Badia, Pantalica Nord grave 28 and Vizzini hoard). Peroni indicates the Final Bronze Age 2 as first appearance of this type. It was in use until BF 3 / I Fe 1A. 2 examples (70582, Fig. 8, and 70839) belong to Fibule ad arco semplice con schema decorativo continuo (type $31 \mathrm{~B}$ ). They have a wide regular bow, a wide catchplate, and a small spring, often with a square section. The herringbone decoration covers the entire bow. The date is Final Bronze Age 3, Pantalica phase II (also called Cassibile-Molino della Badia).

The following types 44 and 47 belong to class VIII FIBULE AD ARCO INGROSSATO DALLA SiCILIA.

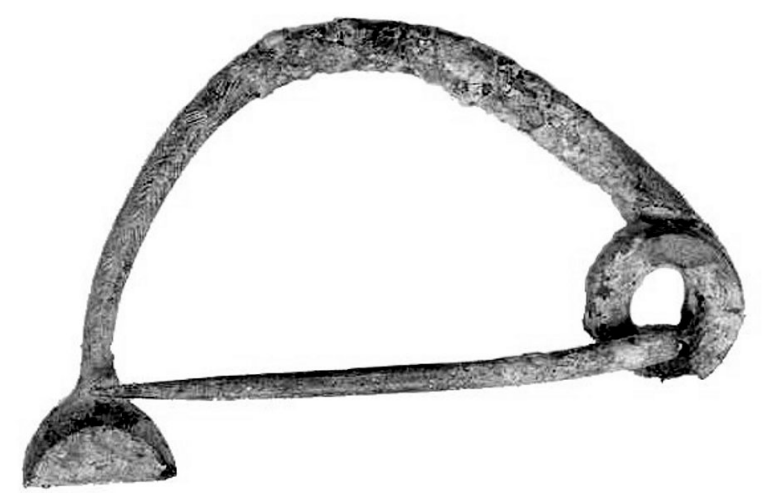

Fig. 8. Fibule ad arco semplice con schema decorativo continuo, inv. n. 70582 (simple bow fibula with continuous decoration). L.: $7,1 \mathrm{~cm}$.
Fibule ad arco ingrossato e decorazione incisa (type 44, here 71375) are of large and medium sizes with a semicircular uniformly thickened bow. The rich and various decoration allows us to distinguish different types. The date is Final Bronze Age 3, as confirmed by an example from the Modica hoard (Lo Schiavo, Albanese Procelli, Giumlia-Mair 2002).

The Fibule ad arco ingrossato ed inornato (type 47, here 70573, Fig. 9) are not homogeneous and are characterised by the absence of decoration and by the wide bow which is mostly not homogeneously thickened. The date is the same of the previous type.

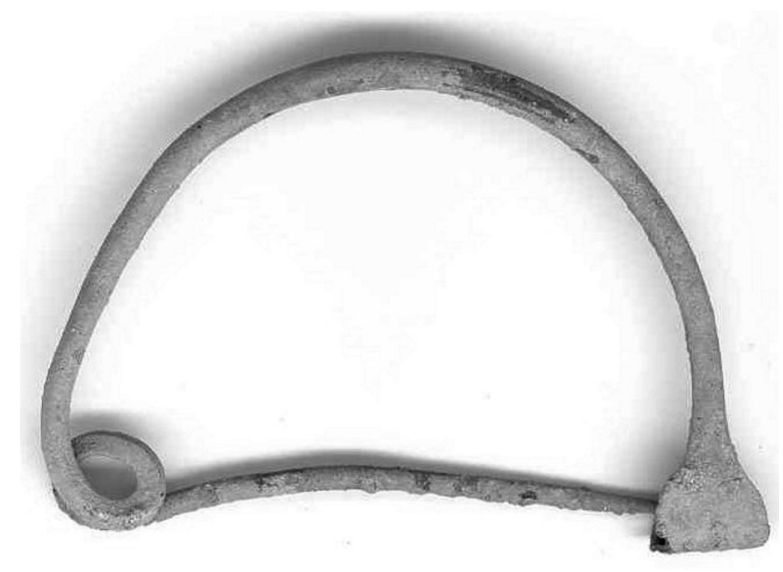

Fig. 9. Fibula ad arco ingrossato ed inornato, inv. n. 70573 (fibula with thickened and non-decorated bow). W.: $7,9 \mathrm{~cm}$.

The fibulae belonging to class IX FIBULE AD ARCO INGROSSATO CON COSTOLATURE LONGITUDINALI E A SEZIONE POLIGONALE O QUADRANGOLARE are typical for Molino della Badia/Madonna del Piano: these are the inhomogeneous types 48: Fibule ad arco ingrossato con costolature longitudinali (n. 71310, Fig. 10) and 49: Fibule ad arco ingrossato e decorato con sezione poligonale (nos. 71144 e 70750). Known examples are medium size, with a wide bow (and in one case a lowered bow). The decoration is different on all pieces. From the characteristics of the artifacts it is evident that they were produced in the workshop of Molino della Badia/Madonna del Piano and are dated to Pantalica II, Final Bronze Age 3.

A further inhomogeneous type from the same workshop and date are the Fibule ad arco ingros- 


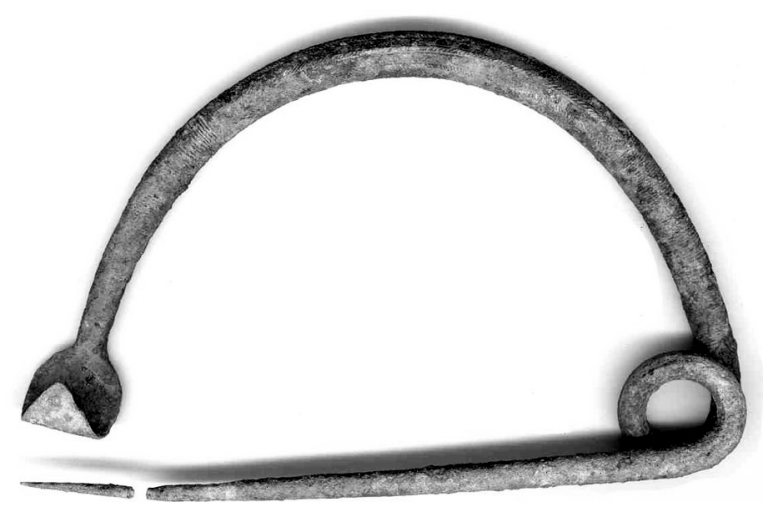

Fig. 10. Fibule ad arco ingrossato con costolature longitudinali, inv. n. 71310 (fibula with thickened bow and longitudinal ribs). W.: $14 \mathrm{~cm}$.

sato con sezione quadrangolare o orizzontalmente appiattita (type 56). The studied piece (71389) is uncommon, because it is not decorated.

Fibule serpeggianti (Fig. 11) belong to class XXXIV: FibUle SERPEGgIANTI A GOMITO. The earliest example analysed is a Fibula serpeggiante a gomito con espansione centrale appiattita e costolata (type 286 A, 70890), characterized by its large size, a thick twisted rod on the fore part (variety A) or by a square section (variety B), both on the front and back of the bow, while in the centre it widens to a rectangular section, with longitudinal ribs on the upper face. Undoubtedly they are of local production and dated to the Final Bronze Age 3.

A further analysed example belongs to the Fibule serpeggianti a gomito decorate, a sezione rettangolare (type 287.2), characterized by large size, open elbow, bow with rectangular section, here decorated on the rim of the upper face by two longitudinal, thin ribs (n. 70721). Fibule serpeggianti a gomito con staffa simmetrica (type 288) are represented by inv. n. 70776, which is near the variety $\mathrm{C}$ of this type: instead of groups of annular lines it shows a continuous decorative pattern. All examples are different, but the type is well characterized and recognizable. The date is Pantalica II, Final Bronze Age 3 as indicated by the piece found at Lipari, at earth level, outside the hut $\alpha$ II, dated to the archaic Ausonio II (Bernabò Brea, Cavalier 1980).

The best represented type are Fibule serpeggianti a gomito con staffa allungata e spillone diritto, tipo Cassibile (type 289), mostly large, with a long bow, pronounced elbow and concave central part. The bow is thickened in the front and central part and becomes thinner near the catchplate, the elbow and the spring. The catchplate is elongated and the size of the spring is proportional to the size of the piece, mostly with a round section and a straight pin. At least 9 main varieties can be distinguished. Also this type is not homogeneous, but well characterised and recognizable.

Among the analysed pieces we have variety $\mathrm{C}$ (n. 70646) with groups of thin longitudinal ribs and groups of lines, and variety F (nos. 71101, 71369), with bands of lines. Other examples show different decorations (nos. 70623, 70395). Some fragmentary fibulae of the Castelluccio di Scicli hoard can be easily classified as belonging to these varieties. Giardino underlined the similarity of the decoration of examples from the hoard of Ria de Huelva, although the production technology is different (Di Stefano, Giardino 1994; Ruiz-Gálvez Priego 1995; Lo Schiavo 1992). Also the Castelluccio hoard is dated to the Final Bronze Age 3. The fibulae from the acropolis of Lipari are difficult to define because of their bad conservation. The shape is altered and there are only traces of decoration. The date can be assigned to the archaic period of Pantalica II, distinctive for Molino della Badia/Madonna del Piano. The pieces from Lipari (possibly the oldest examples), found under the huts $\alpha$ II and $\beta$ IV (archaic Ausonio II), confirm this date.

The Fibule serpeggianti a gomito con antenne a globetto (type 291) are particularly interesting. Of these there are 3 (not identical) examples. One belongs to the Castelluccio hoard and its closest parallel is from Soria or Guadalajara, now in the National Archaeological Museum in Madrid. The Iberian example seems to have a round section and this and the schematic representation of this type on the stelae in Estremadura allow the hypothesis that Iberian workshops produced types similar to the Sicilian fibulae (Di Stefano, Giardino 1994).

Fibule serpeggianti a gomito a contorno quadrangolare (type 293) are also typical. They have in common a quadrangolar bow, with 2 symmetrical and opposite elbows. The analysed example (inv. n. 70606) has no decoration.

Finally a Fibula serpeggiante a contorno quadrangolare con due occhielli, staffa a spirale ed arco foliato con cappi ad 8, da Madonna del Pia- 
XXXIVth class: The Elbow Fibulae
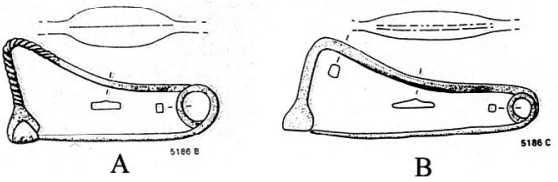

Type 286

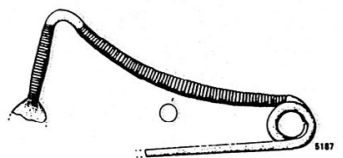

A

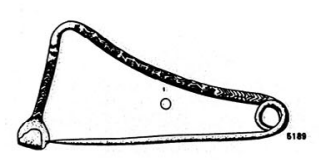

B

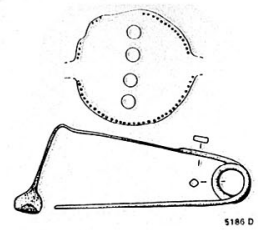

Type 287.1

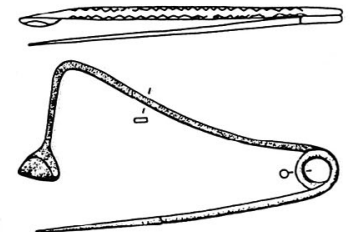

Type $287.2^{\text {ind }}$

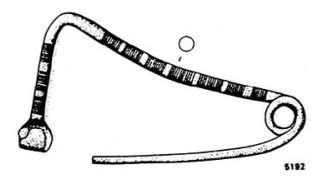

C

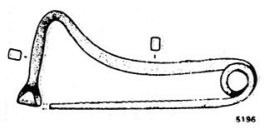

D

Type 288

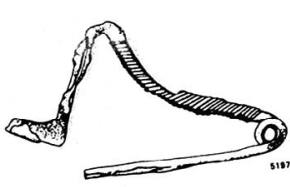

A
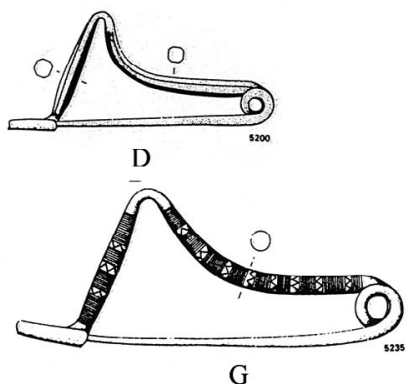

Type 289

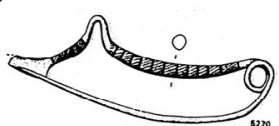

Type 290.1

A

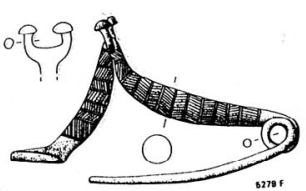

A
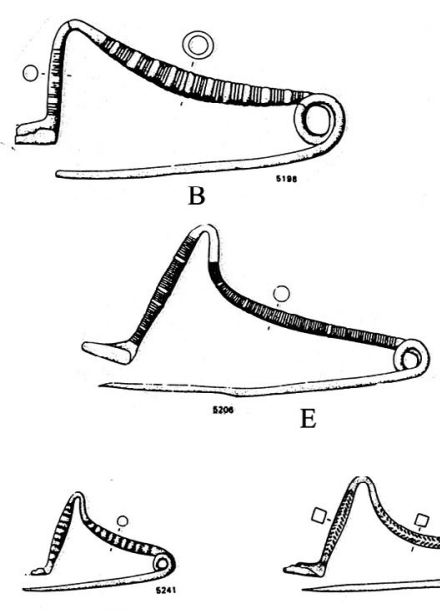

$\mathrm{H}$

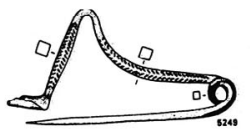

I
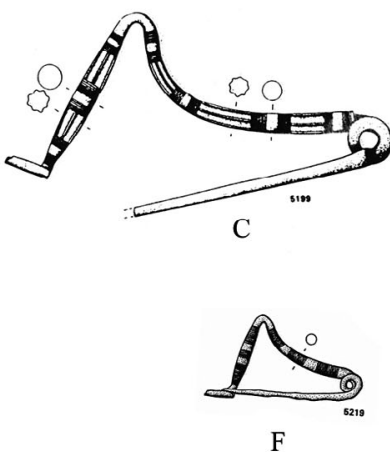

F

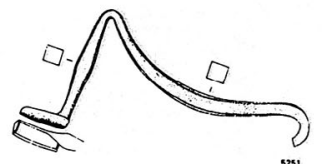

$\mathrm{L}$

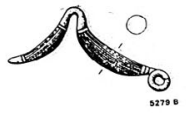

Type 290.2

Type 291

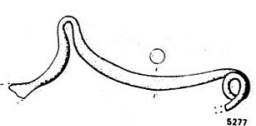

B

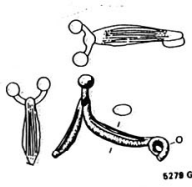

B

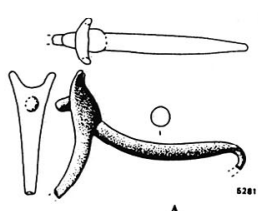

Type 292

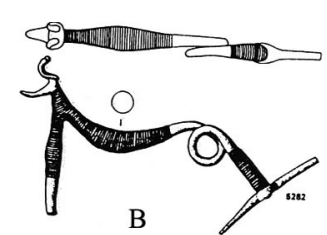

B

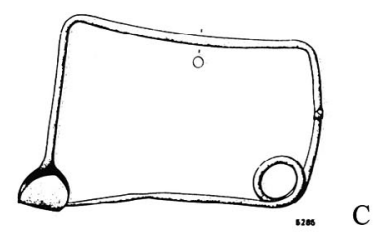

Type 293
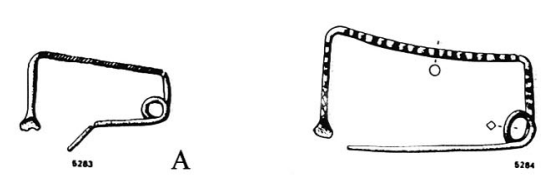

$B$

ㄱ.m

Fig. 11. The different types of fibule a gomito from the necropolis (drawings Lo Schiavo PBF, forthcoming; layout G. Ugolini). 
no (type 297 n. 71204) was also analysed. This type is well characterised and consists of several elements which are found in the full Protovillanovan in Central and Southern Italy and in Sicily. This is the oval plaque with longitudinal edge, the quadrangular bow, the 3 loops and the decoration on the fore part of the bow (cfr. type 289 variety $\mathrm{G}$, also in the necropolis of Madonna del Piano). Parallels to the two 8-shaped loops and the spiral catchplate are found in 2 fibule ad arco di violino di verga of Vösendorf type and two 8-shaped loops and the decorated leaf-shaped bow in the Röschitz-Sanislãu type.

The typological study confirms the data of analysis and indicates the presence of a rich, characteristic, original and variegated local production. The workshop production was not limited to the local market, but it is also found in the entire area of eastern Sicily (and in Lipari), with sporadical finds in other parts of the island, and it is to be dated between the end of the Final Bronze Age (BF 3) and the beginning of the Early Iron Age (I Fe and IA).

There are interesting formal parallels both with Calabria and with the Iberian peninsula. The general impression is that there are affinities and analogies due to the circulation of models and not of objects connected to the dress and the set of ornaments.

\section{FIBULAE AND DECORATIVE OBJECTS OF PERSONAL USE (Alessandra Giumlia-Mair)}

The class of the fibulae is the largest among the finds from Madonna del Piano. The average tin content (Fig. 12) is $9.5 \%$ (range 4.2-11\%). All fibula specimens were first cast (most probably in a simple clay mould) and only slightly wrought, with repeated annealing, after the removal of the casting skin, to obtain a sharp point and form the catchplate. In the group of fibulae analysed for this project the tin content shows a variation of 3 or $4 \%$, however the composition range is always in the alpha phase, i.e. the pieces are can all be worked by hammering and the alloy is always malleable.

The average lead content (Fig. 13) is $1.5 \%$, however the range is $0.1-6.3 \%$ (standard deviation of 1.5) and clearly shows that there is a great variation in the content of this element. Only a

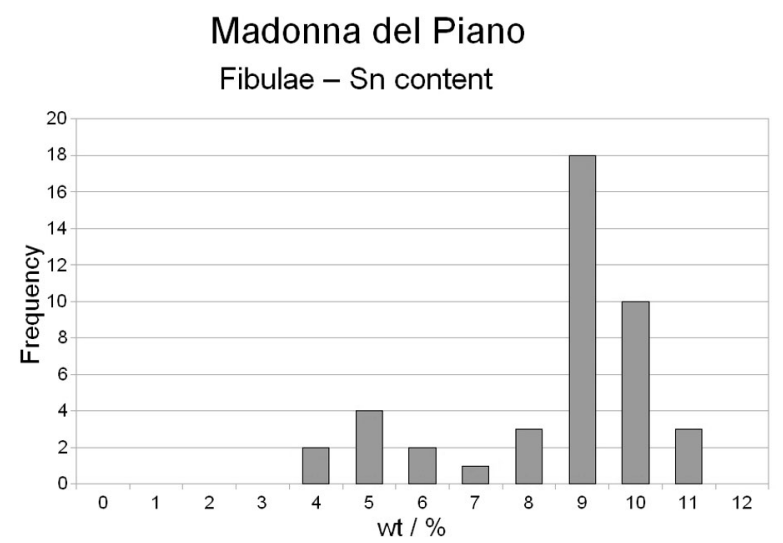

Fig. 12. The histogram shows the tin content in the fibulae. The average Sn content is $9.5 \%$, the range is $4-11 \%$. Only poor quality or miniature fibulae contain less than $7 \%$ of tin.

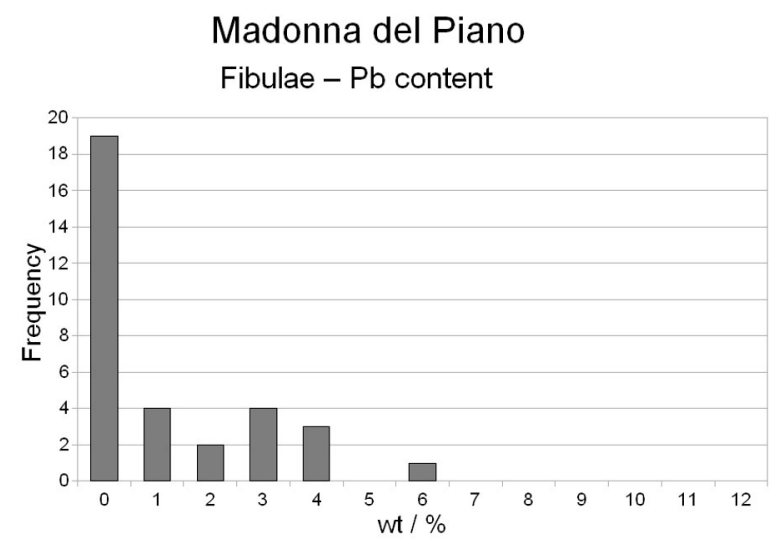

Fig. 13. The histogram shows the lead content of the fibulae. There are not many examples with a lead content over $3 \%$, but high lead is found in cast on parts. Therefore the addition of lead to the alloy seems to be deliberate and correlated with the technology (photos and histograms A. Giumlia-Mair).

few examples of fibula contain percentages of lead higher than $3 \%$. However it is important to note that the pieces which contain more lead seem to be produced in different parts. The fibula with the inv. n. 70582 for example shows very similar tin percentages in the bow and the pin. However, while the lead determined in the pin is very low, in the bow there is a lead content of $6 \%$. As it was the case with some of the fibulae from Modica, it seems that the bow was produced by casting the thickened part on the (elongated and curved) thin bar employed for the pin, by using a leaded alloy. 
In this way the alloy had a high fluidity and reproduced in detail the decoration and there was no risk of ruining the pin, as the cast on part had a lower melting point.

The thickened and decorated parts of the elbow fibula with the inv. n. 71101 (Fig. 14) seem to have been produced in the same way and at the elbow there is also a very evident and quite rough repair, made with an alloy which contains even more lead than the bow. This seems to confirm that in the Sicilian Late Bronze Age leaded alloys were already deliberately and knowingly employed in correlation with technique and use of the piece in production.

A special case is that of the elbow fibula with antennae (inv. n. 71204, Fig. 11, type 291A, or fibula de codo with antennae), of a type which in Sicily is known also from the Castelluccio hoard found at Scicli, near Ragusa. However it has to be mentioned that this type of fibula is found also in Spain, for example in Guadalajara, and it is even represented on the famous stela of Torrejón el Rubio 2 in Cáceres (Ruiz Delgado 1989; Storch de Gracia y Asensio 1989).

The Iberian examples which have been analysed by Carrasco et al. (1999) contain high tin percentages, but no $\mathrm{Pb}$ (with one single exception). Relatively high tin contents have been also determined in the fibulae from Fraga dos Corvos in Portugal (Figuereido et al. 2009), but also in the Iron Age fibulae from Castro de Pragança (Melo 2009). The use of higher tin in copper alloys is not a surprise in a country in which this important metal was easier to find (Penhallurick 1986: 95-104; see also Giumlia-Mair, Lo Schiavo 2003). The example from Madonna del Piano contains $11 \% \mathrm{Sn}$ and it is therefore one of the ob-

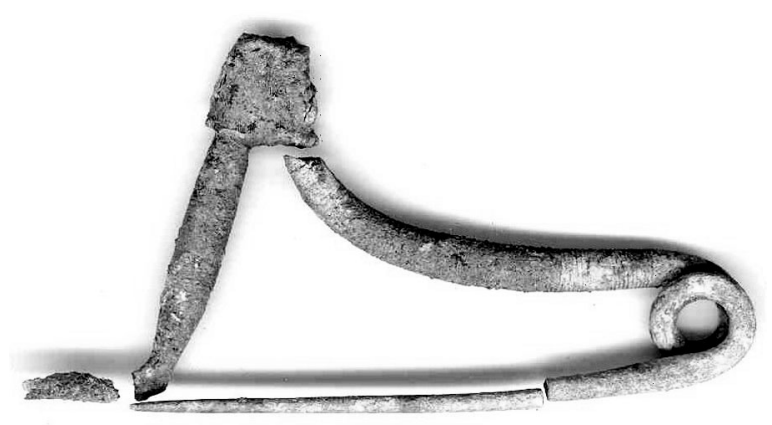

Fig. 14. Elbow fibula with thickened bow and repair inv.n. 71101. W.: $11,5 \mathrm{~cm}$. jects with the highest tin content found in the necropolis.

It is also important to underline that, while in the Italian peninsula no fibulae of this type are known, there are several ones in the Iberian peninsula, both in Spain and in Portugal, but that also other very similar types, called "oriental" or Cypriot types (Buchholz 1985; Lo Schiavo 1992 and in print) exist in various Mediterranean areas, such as for example in Spain, France and Sardinia. A study and in particular chemical analyses of these pieces would be quite important and might allow the reconstruction of the complex relationships between the different shapes and the contacts between the regions in which they are found.

The addition of lead to the alloys for cast-on parts seems for the moment to be a Sicilian invention and it appeared in Northern Italy only 2 or 3 centuries later (Giumlia-Mair 2000; 2005b).

Among the decorative objects of personal use analysed for this project there are also a miniature bow fibula (inv. n. 71375), a miniature fibula of Cassibile -type (inv. n. 71395) and the small spiral-shaped anklets for children (inv. n. 71377 sporadic). It seems quite possible that they have been manufactured for funerary use only, because the alloys employed are of lesser quality, with low tin percentages between 4 and $5 \%$.

\section{KNIVES}

Several knives belonging to the set of grave gifts found in female burials have been analysed. The results have shown that there is a great variation in the composition of their alloys. Some examples show an excellent quality, for example inv. n. 70589 (Fig. 3) and 70577, with the use of a carefully refined copper and a particularly well worked blade. These two specimens might perhaps have been objects of special status and this might also be indicated by the fact that the handle of one of knives (inv. n. 70577) has a handle made of ivory. Other examples of analysed knives (inv. nos. 71353, 71362, 71208 etc.) seem to be of more common manufacture.

In two cases the quality of the bronze used for the rivets which fix the handle on the blade is better than the metal employed for the blade. This seems to indicate that the artisans kept in the workshop small parts, cut from other objects, to 
be worked into rivets. In one case (inv. n. 71353) the blade and the rivets seem to have been made of the same alloy. Most probably the pouring channels had been cut from the blade blank and hammered into rivets.

The largest groups of knives dated to this period which can be compared with the materials from Madonna del Piano are the Greek examples analysed by Craddock $(1976,99)$ and the knives from several central European sites analysed by Riederer (1992: 295-300; 1994-1995). They show similar compositions with an average tin content of $7.8 \%$ (range 5.6-9.2 $\mathrm{Sn} \%$ ). Also the knives from the French Alps analysed by Verney and Bocquet (1998) are chronologically and compositionally comparable, and the saw (clearly a knife blade adapted to a saw) from a Calabrian hoard found south of Kroton and analysed by Alberto Palmieri (Marino and Pizzitutti 2008: 333-334) has a composition very similar to that of the knives from Madonna del Piano.

The Italian knives dated to the Iron Age (Antonacci Sanpaolo et al.1992: 172-173; Craddock 1986; Giumlia-Mair 1998b: 201-202) have tin percentages between 6 and $8 \%$, while in earlier times the tin content of blades was much higher. For example the blades from Moscosi di Cingoli, dated to the Recent Bronze Age contain as much as $19 \%$ of tin and clearly reflect the archaic technology of earlier periods (De Marinis et al. 2003: $21)$. It has to be noted that real bronze was introduced only in the Middle Bronze Age and that tin was an expensive and rare commodity that had to be imported from far away. For a long time arsenical copper was recycled and there are many instances of "strange" alloys: copper was occasionally mixed with other metals, such as lead and even silver as tin substitutes (see for example Tylecote 1976: 14-16; 1986: 26-35; Craddock 1976: 93-113; 1995: 144-17).

The miniature knife inv. n. 71185 from grave 207 (Fig. 4) represents a special case. For this object a bronze with only around $5 \%$ of tin was employed and the blade has a anomalous and awkward arched shape, with a rounded point. In general this knife does not look like an efficient tool, however the suspension ring on the handle shows noticeable traces of wear as if the knife had been regularly worn hanging from the belt. The small size and the composition might suggest that the knife had been produced for funerary use, for example for the burial of a young girl (see above), but the person in the grave is a woman, not a child. In this case, the awkward shape and the traces of wear, as well as the relatively low quality of the alloy, might perhaps indicate that possibly a common blade which had been broken was readapted for further use. The rather low tin content might be due to the reworking of the object. Nevertheless the study and analysis of more miniature knives might represent an interesting topic of research for the future.

\section{TOOLS AND EVERY DAY ITEMS}

In the male burials of the necropolis of Madonna del Piano there is a noticeable number of razors. They have been found in $6 \%$ of the graves, however only very few examples have been analysed for this project, because of the bad conditions of conservation of this kind of objects. The analysed razors are made of bronze with low tin contents of around $6 \%$.

Their composition is similar to that of the knives found in female graves. The Bronze Age razors from Greece have a different composition, with higher tin contents (Craddock 1976).

The lowest tin percentages are those of the already mentioned tools for reeling thread, but in the case of these objects lead is also present in the alloy.

The composition of the razors, knives and tools found in the graves of the necropolis seems to indicate that the alloys for every day objects were not considered important and that cheaper materials were employed.

\section{OBJECTS WITH HIGH TIN CONTENT: BELT ELEMENTS AND TINTINNABULA}

From the metallurgical point of view, the most striking objects from the graves of the necropolis are the wheel-shaped belt elements (Giumlia-Mair 2005a: 362-364). The analyses have shown that they contain a very high tin percentage which goes up to $17 \%$. The belt decorations inv. nos. 71363 and 71209 consist of a flat ring and a smaller ring with an inscribed cross (Fig. 15) and were most probably worn attached to the belt. The alloy of which they are made is very different from that used for the belt-hook 


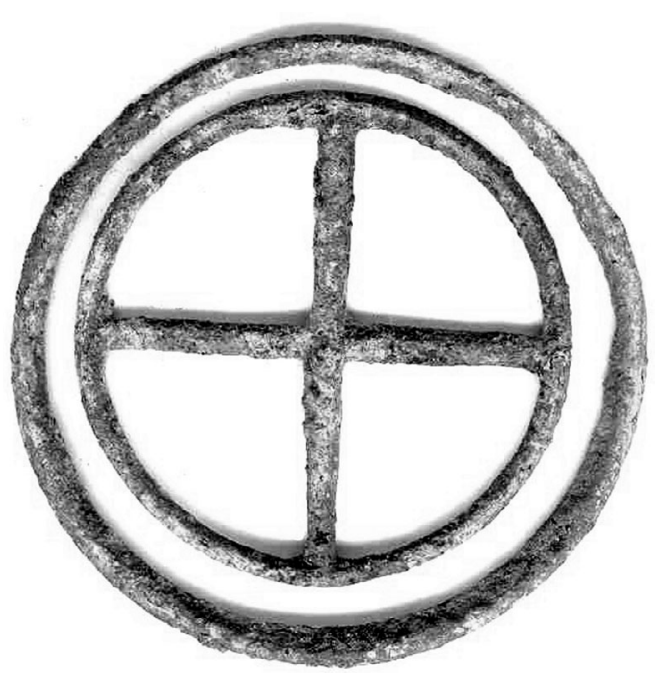

Fig. 15. Wheel-shaped belt decoration. These objects contain high tin percentages. Diam.: ca. $7 \mathrm{~cm}$.

inv. n. 71354 , which contains only $6.3 \%$ of tin and traces of lead.

The massive hook is quite solid and very suitable as a functional part of the belt, while the high tin content renders the wheel-shaped ornaments rather fragile. It does not seem possible that the thin circlets could have had a practical function, such as being an element for fixing or binding the belt. The most probable reasons for choosing an alloy with such a high tin content are the almost silvery colour of the metal, but also the pleasant jingling sound of the decorations, which had most probably an apotropaic function similar to that of the tintinnabula (see below) and kept away the "evil eye". In later times alloys of this composition were employed for bells and tintinnabula, because of their pleasant sound (compare for example Giumlia-Mair 1988; 1992; 1996; 2000b: 303-304; 2001).

The shape and the colour of these belt decorations remind us very closely of the wheel-shaped pendants known from many contexts, in particular around the Alps, but also in some sites in southern Italy (Mordant et al. 1976; Wels-Weyrauch 1978; 1991; Lochner 1998-1999; Bándi and Fekete 1977-1978; Heath et al. 2000; Žbona-Trkman and Bavdek 1995-1996; Trampuž Orel and Heath 2001; Giumlia-Mair 2008; 2009b). They have many different shapes, some of which rather complex, and their colour is invariably silvery. In some cases this is due to the presence of elements like arsenic, antimony, nickel and cobalt in the copper, in other cases the alloy is similar to that of the belt decorations, with a high tin content. Sometimes they seem to have been surface treated, perhaps with some kind of organic acid, so as to oxidise the copper of the alpha phase from the dendritic structure and leave the tin rich and more corrosion resistant dendrites of the delta phase to achieve a silvery colour (Heath et al. 2000; Trampuž Orel and Heath 2001; Giumlia-Mair 2003; 2005a; 2008; Paulin et al. 2003; Angelini et al. 2007).

As noted by Peter Turk (2001), wheel pendants - obviously with the exception of the ones belonging to hoards - have been found in particularly rich female burials, together with representative jewellery and other precious gifts. In each necropolis there was never more than one such grave for each generation and this seems to indicate that the person who was wearing this ornament had some special function in the society of the time. Biba Teržan (1987) considers them persons who had exceptional importance in the settlements and suggests that they were entitled to perform special rituals or ceremonies in favour of the community they belonged to.

Pendants of different shape, but surprisingly made of the same material, i.e. with the same silvery colour and found in very rich female graves and in similar contexts of the full Iron Age, have recently been recognised (Giumlia-Mair 2008; $2009 b$ ). The materials coming from the same necropolis had been previously analysed (GiumliaMair 1995; 1998a; c; 2003; 2003b; Giumlia-Mair et al. 2003) and they were all normal bronzes or leaded bronzes. The pendants and the set of ornaments belonging to them were the only objects made of this kind of alloy among several hundreds of items made of common bronze or leaded bronze.

This is certainly an important detail which might perhaps shed some light also on the meaning of the wheel-shaped belt ornaments from Madonna del Piano, and from other southern Italian cemeteries. The date, the shape and the colour are more or less the same as the wheel pendants, even if in some cases the colour is achieved by using different materials and alloys. In addition the belt decorations are found in particularly rich graves and they might be a distinctive object which denoted the special status of the woman who was wearing them. 
The motive of the wheel is found all over Europe, and up to Scandinavia and it seems to belong to the general and diffused religious beliefs of the Bronze Age (but also of later times) and to be a powerful symbol in the society of the time.

In the past the wheel pendants have been interpreted as solar or lunar symbols, connected with fertility and water (Kossak 1954; 1990). Because of their colour, and as they always belong to women, the lunar context seems to be the better interpretation.

One of the two tintinnabula analysed (inv. n. 71360) has been found in the grave of the woman who was wearing one of the wheel-shaped belt decorations and it consists of 12 tubuli with 4 different diameter sizes, made of sheet metal, and 10 small rings, which were most probably worn as a pectoral. The tubuli and rings are made of alloys which contain up to $15 \%$ of tin. Their different sizes definitely produced different chimes.

In this case it is difficult to reconstruct the original shape of the tintinnabulum, however the second piece, inv. n. 71155 (Fig. 2), is more complete in its part and a reconstruction can be attempted. The composite object consists of a perforated bar with 14 holes, 14 bronze tubules of the same size and composition, and 7 rings of different sizes. The tubules are made of well purified bronze with around $11 \%$ of tin. The rings are all made of the same alloy, which contains over $15 \%$ of tin.

The tubuli were most probably hanging from threads passing through the perforations in the bar. In this grave there was also a small cast figurine of an animal resembling a calf, vertically perforated through the centre from which the threads might have been suspended. Similar objects have been found also in other graves containing tintinnabula pectorals, except in one case in which only a bull figurine with a fibula was present and there were no tubuli. It seems that the zoomorphic part belonged to the same set or it could have been worn separately.

By tinkling at each step and movement, the tintinnabula had with all probability an apotropaic function and kept away the "evil eye", but they also attracted attention to the person who was wearing them and emphasised the richness of the attire.

\section{CONCLUSIONS (A. Giumlia-Mair, R.M. Albanese Procelli, F. Lo Schiavo)}

The analysis results allow us to draw conclusions on the technology level of the local community and the everyday habits and some funerary practice. They allow the hypothesis that the miniature objects found in children's burials are not functional, but were produced for funerary use only. The quality control in the swords production and in the manufacture of complex objects as the tintinnabula demonstrate the sophistication of the local workshops.

Comparisons with objects from the south of Italy, particularly Calabria, reveal close relationships, however our research on Sicilian material is for the moment pioneering work. Analyses of Campanian, Calabrian and Apulian contemporary material are still needed. In particular it would be interesting to extend the metallugical analyses to Calabrian cemeteries on the Tyrrhenian coast (Torre Galli) and in the Locris area and (Canale, Janchina, Patariti) so as to examine the further developments of the production. Much more data is needed to establish the kind of relationship between Sicilian and Iberian elbow-type fibulae and which elements played a role in the production of these particular objects. Nevertheless it is quite important to note that this is (at least up to now) the earliest scientifically determined occurrence in Italy of the use of lead as alloying element employed in correlation with the production technique. The Sicilian cast-on technique in the production of thickened elbow fibulae segments has never been documented before.

The complete study of the finds from Madonna del Piano will be published in the Notizie di Scavi d'Antichità.

\section{BIBLIOGRAPHY}

Albanese Procelli, R.M. 1992: "La necropoli di Madonna del Piano presso Grammichele: osservazioni sul rituale funerario". Kokalos XXXVIII: 33-68.

Albanese Procelli, R.M. 1994: "Considerazioni sulla necropoli di Madonna del Piano di Grammichele (Catania)". In AA.VV.: La presenza etrusca nella Campania meridionale, Atti delle giornate di studio Salerno-Pontecagnano, 16-18 novembre 1990, Firenze: 153-169.

Albanese Procelli, R.M. 2003: Sicani, Siculi, Elimi, Longanesi, Milano. 
Albanese Procelli, R.M. La Piana S. forthcoming $L a$ necropoli di Madonna del Piano presso Grammichele (Catania). Campagne di scavo 1970-1971, Notizie degli Scavi di Antichità.

Albanese Procelli, R.M. and Lo Schiavo, F. 2004: "La comunità di Madonna del Piano presso Grammichele (Catania): rapporti con l'area calabra". In Preistoria e protostoria della Calabria, Atti XXXVII Riunione Scientifica dell'Istituto Italiano di Preistoria e Protostoria (Scalea, Papasidero, Praia a Mare, Tortora, 29 sett.-4 ott. 2002), Firenze: 403-420.

Angelini, I.; Frizzi, T.; Alberti, R.; Masiero, E.; Artioli, G.; Molin, G. and Venturino Gambari, M. 2007: "Snapshot of a Final Bronze Age metalworker: archaeometallurgical study of the hoard and the working tools from Chiusa di Pesio, Cuneo, Italy", Proceedings of the $2^{\text {nd }}$ International Conference Archaeometallurgy in Europe 2007, 17-21 June 2007, Aquileia, Italy, Digital publication on CD.

Antonacci Sanpaolo, E.; Canziani Ricci, C. and Follo, L. 1992: "Il deposito di San Francesco (Bologna) ed il contributo delle indagini archeometallurgiche". In: Archeometallurgia, ricerche e prospettive, E. Antonacci Sanpaolo, ed., Bologna: 159-206.

Bándi, G. and Fekete, M. 1977-1978: "Újabb bronzkincs Velem-Szentvidem". Savaria XI-XII:101-133, Figs. 20-22.

Bernabò Brea, L.; Militello, E. and La Piana, S. 1969: "Mineo (Catania). La necropoli detta del Molino della Badia: nuove tombe in contrada Madonna del Piano". Notizie degli Scavi di Antichità XXIII: 210-276.

Buchholz, H.-G. 1985: "Ein kyprischer Fibeltypus und seine auswärtige Verbreitung". In: Cyprus between the Orient and the Occident. Acts of the International Archaeological Symposium, Nicosia 8-145 Sept. 1985, Nicosia: 233-244.

Carrasco, J.; Pachón, J.A.; Esquivel, J.A. and Aranda, G. 1999: "Clasificación secuencial tecno-tipológica de las fíbulas de codo de la Península Ibérica". Complutum X: 123-142.

Craddock, P.T. 1976: "The composition of the copper alloys used by the Greek, Etruscan and Roman civilisations. 1. The Greeks before the Archaic period". Journal of Archaeological Science III: 93-113.

Craddock, P.T. 1986: "The metallurgy of Italic and Sardinian bronzes". In Italian Iron Age Artefacts. $6^{\text {th }}$ British Museum Classical Colloquium, J. Swaddling, ed., London: 143-149.

Craddock, P.T. 1995: Early Metal Mining and Production, Edinburgh University Press, Edinburgh.

De Marinis, G.; Giumlia-Mair, A.; Miccio, M. and Sabatini, T. 2003: "La Metallurgia, in Moscosi di Cingoli e Cisterna di Tolentino: due siti dell'età del Bronzo a confronto". XXXVIII Riunione Scientifi- ca, Portonovo-Abbadia di Fiastra, 30 Settembre-5 Ottobre 2003, Ministero per i Beni e le Attività Culturali, Soprintendenza per i beni Archeologici delle Marche, Roma: 20-22.

Di Stefano, G. and Giardino, C. 1990-91 (1994): "Scicli (Ragusa) Il ripostiglio di bronzi in contrada Castelluccio sull'Irminio". Notizie degli Scavi di Antichità IX, I-II, Roma: 489-546.

Figueiredo, E.; Senna-Martínez, J.C.; Silva, R.J.C. and Araújo, M.F. 2009: "Studies on orientalising artefacts from the Hoard of Fraga dos Corvos, in North Portugal". In A. Giumlia-Mair (ed.): Manufacturing Techniques from Prehistory to the Renaissance, Special number of Materials and manufacturing processes XXIV, 9, 949-954.

Giumlia-Mair, A. 1988: "Die phönizischen Kupferlegierungsobjekte aus Morro de Mezquitilla im Vergleich mit Gebrauchsgegenständen anderer Mittelmeerkulturen- Zusammensetzung und Verarbeitung”. In: Griechische und römische Statuetten und Großbronzen, Akten der 9.Tagung über antike Bronzen in Wien, April 1986. Wien: 210-213.

Giumlia-Mair, A. 1992: "The composition of minor copper-based finds from a West Phoenician settlement site and from Nimrud in comparison with contemporary Mediterranean small finds". Archaeometry. Bulletin of the Research Laboratory for Archaeology and the History of Art, Oxford. 34, 1 (1992): 107-119.

Giumlia-Mair, A. 1995: "The copper-based finds from a Slovenian Iron Age site". Bulletin of the Metals Museum, Sendai, Japan. XXIII I: 59-81.

Giumlia-Mair, A. 1996: "Roman copper-based finds from a Slovenian settlement". The Bulletin of the Metals Museum, Sendai, Japan, XXV, I: 48-63.

Giumlia-Mair, A. 1998a: "The metallurgy of the copper based artefacts from the iron age necropolis of S.Lucia/Most na Soèi”. In: Proceedings of the XIII International Congress of Prehistoric and Protohistoric Sciences, Forlì 1996, 4 Sections: 665-672.

Giumlia-Mair, A. 1998b: "Studi tecnici sui bronzi dall'officina dei Ciastjei": In: P. Cassola Guida, S. Pettarin, G. Petrucci, A. Giumlia-Mair, Pozzuolo del Friuli, II, 2, La prima età del ferro nel settore meridionale del castelliere. Le attività produttive ed i resti faunistici, Quasar, Roma: 181-230.

Giumlia-Mair, A. 1998c: "La metallurgia dei bronzi di S.Lucia / Most na Soèi”. Aquileia Nostra, LXIX 30: 135.

Giumlia-Mair, A. 2000: "Bronze technology in the Eastern Alpine regions between the Final Bronze Age and the Early Iron Age". In Giumlia-Mair (ed.): Proceedings of the Workshop on Ancient Metallurgy between Oriental Alps and Pannonian Plain, 29-30 Ottobre, Dipartimento di Ingegneria 
dei Materiali e Chimica Applicata, Università di Trieste. Quaderni di Aquileia Nostra VIII: 77-91.

Giumlia-Mair, A. 2000b: "Argento e leghe 'argentee' nell'antichità". Atti del 7. ${ }^{\circ}$ Convegno Le Schienze della Terra e L'Archeometria, Taormina, Palermo, Catania, 22-26 febbraio 2000, AIAr, Bollettino dell'Accademia Gioenia di Scienze Naturali XXXIII 357 (II): 295-314.

Giumlia-Mair, A. 2001: "Technical studies and chemical analysis of the Roman copper-based finds from Emona”. Berliner Beiträge der Archäometrie XVIII 2001: 5-42.

Giumlia-Mair, A. 2003: "Iron Age tin in the Oriental Alps". In A. Giumlia-Mair and F. Lo Schiavo (eds.): Le problème de l'étain à l'origine de la métallurgie/The Problem of Early Tin, Acts of the XIVth UISPP Congress, University of Liège, Belgium, 2-8 September 2001, Section 11, Bronze Age in Europe and the Mediterranean, Symposium 11.2, Bar International Series 1199: 93-108.

Giumlia-Mair, A. 2003b: La necropoli di Misincinis. La metallurgia nell'Età del Ferro, Arti Grafiche Friulane, Tavagnacco, Udine.

Giumlia-Mair, A. 2005a: "Tin-rich layers on ancient copper-based objects". In A. Giumlia-Mair (ed.): Proceedings of the Conference SMT18, $18^{\text {th }}$ International Conference on Surface Modification Technologies, Symposium A on Arts and Surfaces, Dijon, France, 15-17 November 2004, Surface Engineering, December 2005, 21, n. 5-6, Maney for the Institute of Materials, Minerals and Mining, London: 359-367.

Giumlia-Mair, A. 2005b: "Copper and copper alloys in the southern Alps". Archaeometry XLVII (2): 275-292.

Giumlia-Mair, A. 2008: "The metal of the moon goddess". In A. Giumlia-Mair (ed.): Proceedings of the Arts and Surfaces session, SMT 21, Paris, 24-26 September 2007, Special Number of Surface Engineering, XXIV (2): 110-117.

Giumlia-Mair, A. 2009a: "The hoard under the $\alpha$ II hut on the acropolis of Lipari. A metallurgical study". In F. Lo Schiavo, R. Maddin, J.D. Muhly, A. Giumlia-Mair (eds.): Oxhide Ingots in the Central Mediterranean, Biblioteca di Antichità Cipriote 8, ICEVO-CNR, Roma: 161-221.

Giumlia-Mair, A. 2009b: "Ancient Metallurgical traditions and connections around the Caput Adriae". Proceedings of the Round Table on Ancient Metallurgy, Beograd University, September 2008, Special Number of Journal of Mining and Metallurgy XLV (I) B 2009: 149-168.

Giumlia-Mair, A.; Keall, E.; Stock, S. and Shugar, A. 2000: "Copper-based implements of a newly identified culture in Yemen". Journal of Cultural Heritage 1: 37-43.
Giumlia-Mair, A.; Keall, E.; Stock, S. and Shugar, A. 2002: "Investigation of a copper hoard from the megalithic site of Al-Midamman, Yemen: an interdisciplinary approach in search of a chronology". Journal of Archaeological Science XXIX: 195-209.

Giumlia-Mair, A. and Lo Schiavo, F. 2003: "Technical studies on Italian LBA/EIA copper-based fibulae". In Proceedings of the fifth International Conference on "The Beginnings of the Use of Metals and Alloys" Buma V, Messages from the History of Metals to the Future Metal Age, April 21-24 2002, Gyeongju, Korea: 311- 322.

Giumlia-Mair, A.; Vitri, S. and Corazza, S. 2003: "Iron Age copper-based finds from the necropolis of Paularo in the Italian Oriental Alps". In Archaeometallurgy in Europe 2003, International Conference, 24-26 September 2003, Museo Nazionale della Scienza e della Tecnologia Leonardo da Vinci, Milan, Associazione Italiana di Metallurgia ed., Milan, II: 157-166.

Heath, D.J.; Trampuž-Orel, N. and Milič, Z. 2000: "Wheel-shaped pendants: evidence of a LBA metal workshop in the Caput Adriae". In A. Giumlia-Mair (ed.): Proceedings of the Workshop Ancient Metallurgy between Oriental Alps and Pannonian Plain, Quaderni dell'Associazione Nazionale per Aquileia 8, Trieste, 2000, 53-70.

Kossak, G. 1954: "Studien zum Symbolgut der Urnenfelder- und Hallstattzeit Mitteleuropas". Römisch-Germanische Forschungen 20.

Kossak, G. 1990: "Kulturgerät, Weihgabe und Amulett aus spätbronzezeitlichen Seeufersiedlungen". Archäologie der Schweiz XIII / 2: 89-100.

Lochner, M. 1998-1999: "Ein Schmuckdepot der Urnenfelderzeit aus Thunau am Kamp, Niederösterreich", Archaeologia Austriaca, Band 82-83: 181-186.

Lo Schiavo, F. 1992: "Un'altra fibula 'cipriota' dalla Sardegna", In Sardinia in the Mediterranean: a footprint in the sea, Studies in Sardinian Archaeology presented to Miriam S. Balmuth, Sheffield: 296-303.

Lo Schiavo, F. 2003: "Le Fibule di Bronzo dell'Italia Meridionale dalle origini al VI sec. a.C. - Materiali e Tecnica". In E. Formigli (ed.): Fibulae. Dall'età del bronzo all'Alto Medioevo: tecnica e tipologia, Sistema Musei Senesi, Quaderni Archeologici 4, Antiquarium di Poggio Civitate, Comune di Murlo, Firenze: 19-39.

Lo Schiavo, F. 2008: "Nuovi documenti dell'età del ferro dalla Calabria tirrenica e dal suo entroterra". In La Calabria tirrenica dell'antichità. Nuovi documenti e problematiche storiche, Arcavacata di Rende, 23-25 nov. 2000, Soveria Mannelli: 9-52. 
Lo Schiavo, F. 2009: "Fibule a gomito di tipo elimo ed altre fibule da Erice e Segesta". In C. Ampolo (ed.): Immagine e immagini della Sicilia e di altre isole del Mediterraneo antico, vol. II, Pisa: 739-742.

Lo Schiavo, F. in print: 'Le fibule dell'Italia meridionale e della Sicilia dall'età del bronzo recente al VI secolo a.C.". Prähistorische Bronzefunde, Abt. XIV Band 14.

Lo Schiavo, F.; Albanese Procelli, R.M. and Giumlia-Mair, A. 2002: "La produzione e la tecnologia metallurgica a Madonna del Piano (Mineo, Catania)". In Giumlia-Mair (ed.): I Bronzi Antichi: Produzione e tecnologia, Atti del XV Congresso Internazionale sui Bronzi Antichi, Grado-Aquileia 22-26 maggio 2001, Monographies Instrumentum XXI, Éd. M. Mergoil, Montagnac: 76-88.

Lo Schiavo, F.; Giumlia-Mair, A.; Sanna, U. and Valera, R. 2005: Archaeometallurgy in Sardinia from the origin to the Early Iron Age, Monographies Instrumentum XXX, Éd. M. Mergoil, Montagnac.

Lo Schiavo, F.; Giumlia-Mair, A. and Albanese Proce1li, R.M. 2009: "Oxhide ingots in Sicily". In F. Lo Schiavo, J. Muhly, R. Maddin, A. Giumlia-Mair (eds.): The oxhide ingots in the central Mediterranean, Biblioteca di Antichità Cipriote 8, Icevo-Cnr, Roma: 135-221.

Lo Schiavo, F.; Muhly, J.; Maddin, R. and Giumlia-Mair, A. 2009: The oxhide ingots in the central Mediterranean, Istituto di Studi sulle civiltà dell'Egeo e del Vicino Oriente, Biblioteca di Antichità Cipriote 8 , ICEVO-CNR, Roma.

Marino, D. and Pizzitutti, G. 2008: "Un ripostiglio di bronzi dal territorio a sud di Crotone (Calabria centro-orientale)". Rivista di Scienze Preistoriche LVIII: 321-336.

Melo, A.A.; Figueiredo, E.; Araújo, M.F. and Senna-Martínez, J.C. 2009: "Iron Age Fibulae from Castro de Pragança (Portugal)". In A. GiumliaMair (ed.): Manufacturing Techniques from Prehistory to the Renaissance, Special number of Materials and manufacturing processes, Vol. XXIV, 9: 955-959.

Mordant, C.; Mordant, D. and Prampart, J.-Y. 1976: "Le dépôt de bronze de Villethierry, Yonne" Gallia Préhist., XI suppl.

Orsi, P. 1905: "Necropoli e stazioni sicule di transizione. V. Necropoli al Molino della Badia presso Grammichele", Bullettino di Paletnologia Italiana XXXI: 96-133.

Paulin, A.; Spaić, S.; Zalar, A. and Trampuž-Orel, N. 2003: "Metallographic analysis of 3000-years-old Kanalski Vrh hoard pendant". Materials Characterization LI: 205-218.

Penhallurick, R.D. 1986: Tin in Antiquity, The Institute of Metals, London.
Procelli, E. and Albanese, R.M. 2003: "Riti funerari dell'età del Bronzo in Sicilia". In Le comunità della preistoria italiana. Studi e ricerche sul Neolitico e le Età dei metalli, Castello di Lipari, 2-7 giugno 2000, Atti XXXV Riunione Scientifica dell' Istituto Italiano di Preistoria e Protostoria I, Firenze: 323-341.

Riederer, J. 1992: "Die Metallanalysen der Bronzeobjekte des Hortfundes von Lengyeltóti". Acta Praehistorica et Archaeologica XXIV: 295-300.

Riederer, J. 1994-1995: “Die Metallanalyse der Schwerter des Hortfundes von Berlin-Buch". Acta Praehistorica et Archaeologica XXVI-XXVII: 129-131.

Rovira, S. 1995: "Estudio arqueometalúrgico del depósito de la ría de Huelva". In Marisa Ruiz-Gálvez Priego (ed.): Ritos de paso y puntos de paso. La ría de Huelva en el mundo del Bronce Final Europeo, Universidad Complutense, Madrid: 33-57.

Rovira, S. and Gómez, P. 1998 “The Ría de Huelva hoard and the Late Bronze Age metalwork: a statistical approach". In C. Mordant, M. Pernot and V. Rychner (eds.): L'Atelier du bronzier en Europe $d u X X^{e}$ au VIII siècle avant notre ère. I, Les Analyses de composition du métal: leur apport à l'archéologie de l'Âge du Bronze, Cths, Paris: 81-90.

Ruiz Delgado, M.M. 1989: Fíbulas Protohistóricas en el Sur de la Península Ibérica, Univ. de Sevilla, n. 112: 31-67.

Ruiz-Gálvez Priego, M. 1995: Ritos de Paso y Puntos de Paso. La Ría de Huelva en el mundo del Bronce Final Europeo, Universidad Complutense, Madrid.

Storch de Gracia y Asensio, J.J. 1989: “La fíbula en la Hispania antigua: las fíbulas protohistóricas del Suroeste peninsular." Tesis Doctoral n. 39 / 89, Universidad Complutense, Madrid: 109-137.

Teržan, B. 1987: "Verovanie in obredi". In B. Teržan (ed.): Depojske in posamezne kovinske najdbe bakrene in bronaste dobe na Slovenskem/Hoards and individual Metal Finds from the Eneolithic and Bronze Ages in Slovenia, Catalogi et Monographiae, I-II, Narodni Muzej, Ljubljiana: 65-78.

Trampuž-Orel, N. and Heath, D.J. 2001: "Depo Kanalski Vrh - študija o metalurškem znanju in kovinah na začetku 1. tisočletja pr. n. š.". Arheološki vestnik LII: 143-171.

Turk, P. 2001: "The weight of objects in late Bronze age hoards in Slovenia and possibilities for determining weight standards". Arheološki vestnik VII: 249-279.

Tylecote, R.F., 1976: A History of Metallurgy, The Metals Society, London.

Verney, A. and Bocquet, A. 1998: "La composition élémentaire d'objets du bronze final des Alpes françaises". In C. Mordant, M. Pernot and V. Rychner (eds.): L'Atelier du bronzier en Europe du XXe au VIII siècle avant notre ère, Les Analyses 
de composition du métal: leur apport à l'archéologie de l'Age du Bronze, Cths, Paris: 101-118.

Wels-Weyrauch, U. 1978: "Die Anhänger und Halsringe in Südwestdeutschland und Nordbayern". Prähistorische Bronzefunde XI / 1, Mainz.

Wels-Weyrauch, U. 1991: "Die Anhänger in Südbayern". Prähistorische Bronzefunde XI / 5, Mainz.
Žbona-Trkman, B. and Bavdek, A. 1995-96: "The Hoards from Kanalski Vrh”. In B. Teržan (ed.): Depojske in posamezne kovinske najdbe bakrene in bronaste dobe na Slovenskem / Hoards and individual Metal Finds from the Eneolithic and Bronze Ages in Slovenia, Catalogi et Monographiae, I-II, Narodni Muzej, Ljubljana, 31-71.

\begin{tabular}{|c|c|c|c|c|c|c|c|c|c|c|c|c|c|c|}
\hline Nr. & Object & $\begin{array}{l}\text { Nr. } \\
\text { Inv. }\end{array}$ & Part & $\mathrm{Cu}$ & Sn & $\mathbf{P b}$ & As & $\mathbf{S b}$ & $\mathrm{Fe}$ & $\mathbf{N i}$ & Co & Ag & $\mathbf{Z n}$ & Mn \\
\hline 1 & fibula & 70750 & bow & 91,2 & 6,3 & 0,08 & 0,02 & 0,04 & 0,2 & 0,04 & & & 0,1 & \\
\hline 2 & disc & 70751 & & 88,5 & 8,9 & 0,02 & 0,02 & 0,02 & 0,1 & 0,01 & & & & \\
\hline 3 & razor & 77150 & blade & 90,3 & 6,2 & & 0,03 & & & & & & & \\
\hline 4 & knife & 70589 & blade & 87,1 & 11,0 & 1,50 & 0,01 & 0,03 & 0,2 & & & & & \\
\hline 5 & pin & 70579 & & 90,2 & 7,4 & 0,05 & 0,07 & & 1,2 & & & tr. & & \\
\hline 6 & knife & 70577 & blade & 83,9 & 14,0 & 0,03 & & & 0,5 & & & & & \\
\hline 7 & knife & 70577 & rivet 1 & 98,0 & - & tr. & tr. & & 1,8 & & 0,01 & & & \\
\hline 8 & knife & 70577 & rivet 2 & 97,0 & - & tr. & & & 2,3 & & & & 0,6 & \\
\hline 9 & ring & 70580 & & 86,2 & 8,2 & 3,00 & 0,20 & & 0,4 & & & & & \\
\hline 10 & fibula & 70573 & bow & 88,9 & 9,8 & 0,20 & & & 0,2 & & & & & \\
\hline 11 & ring & 70574 & & 87,7 & 11,0 & & tr. & & tr. & & & & & \\
\hline 12 & sword & 70870 & blade & 90,2 & 7,9 & 0,70 & 0,40 & & 0,4 & & & tr. & & \\
\hline 13 & sword & 70870 & rivet 1 & 89,4 & 8,0 & 0,90 & 0,20 & & 0,8 & & & & 0,3 & \\
\hline 14 & sword & 70870 & rivet 2 & 91,2 & 7,0 & 0,70 & & & 0,5 & & & & 0,2 & \\
\hline 15 & fibula & 70582 & pin & 91,7 & 5,6 & tr. & 0,10 & & & & & & & \\
\hline 16 & fibula & 70582 & bow & 87,8 & 5,3 & 6,32 & 0,20 & & & & & & 0,4 & \\
\hline 17 & fib. bow s. & 70617 & bow & 88,1 & 9,1 & 1,50 & & & 0,4 & & & & & \\
\hline 18 & fib. bow s. & 70617 & pin & 89,2 & 10,0 & 0,10 & & & 0,1 & & & & & \\
\hline 19 & point & 70870 & & 89,6 & 9,7 & tr. & 0,20 & 0,10 & 0,3 & & 0,01 & & & \\
\hline 20 & scabbard sh. & 70870 & sheet & 98,8 & - & - & 0,10 & - & 0,4 & & & & 0,3 & \\
\hline 21 & rivet & 70870 & rivet & 89,3 & 9,2 & & 0,40 & 0,10 & tr. & tr. & & & & \\
\hline 22 & rivet & 70870 & rivet & 93,7 & 5,7 & 0,50 & & & 0,1 & & & & & \\
\hline 23 & fib. elbow & 70623 & pin & 90,2 & 9,2 & tr. & 0,20 & & 0,5 & $\operatorname{tr}$. & tr. & & tr. & tr. \\
\hline 24 & fib. elbow & 70623 & bow & 89,8 & 10,0 & 2,20 & & tr. & 0,5 & & & & tr. & \\
\hline 25 & razor & 70593 & blade & 90,1 & 6,7 & & & & 0,1 & & & & & \\
\hline 26 & razor & 70593 & handle & 89,8 & 7,2 & & 0,03 & & & & & & & \\
\hline 27 & f. foliata & 70792 & spring & 90,7 & 9,2 & & & & & & & & & \\
\hline 28 & simple bow f. & 70839 & bow & 90,6 & 8,5 & 0,07 & & & 0,03 & & & & & \\
\hline 29 & simple bow f. & 70839 & bow & 90,8 & 8,0 & 0,10 & & & 0,4 & & & & & \\
\hline 30 & simple bow f. & 70839 & pin & 89,2 & 8,8 & - & & & 0,1 & & & & & \\
\hline 31 & fibula & 71310 & pin & 87,8 & 10,3 & 0,20 & & & 0,2 & & & & & \\
\hline 32 & fibula & 71310 & catchplate & 87,5 & 11,0 & 0,10 & & & 0,8 & & & & & \\
\hline 33 & fib. elbow rit. & 70890 & pin & 87,2 & 8,1 & 2,60 & 0,04 & 0,30 & 0,5 & $\operatorname{tr}$. & & & 0,3 & tr. \\
\hline 34 & fib. elbow 1 . & 70721 & pin & 92,5 & 6,0 & 0,20 & & & 0,3 & & & & & \\
\hline 35 & fib. elbow 1 . & 70721 & spring & 91,8 & 6,5 & 0,20 & tr. & & 0,2 & tr. & & tr. & & \\
\hline 36 & fib. elbow 1 . & 70776 & pin & 88,3 & 11,0 & 0,30 & & & 0,2 & & & & & \\
\hline 37 & fib. elbow 1 . & 70646 & bow & 89,1 & 10,0 & 0,10 & & 0,10 & 0,7 & & & & & \\
\hline 38 & fib. elbow 1 . & 70646 & bow d. & 87,4 & 10,0 & 0,20 & & & 1,4 & & & & & \\
\hline 39 & fib. elbow 1 . & 70646 & catchplate & 88,7 & 9,8 & 0,20 & & & 1,3 & & & & & \\
\hline 40 & fib. elbow rep. & 71101 & repair & 81,2 & 11,0 & 3,50 & 0,60 & 0,30 & 1,2 & tr. & & tr. & tr. & \\
\hline 41 & fib. elbow rep. & 71101 & bow & 86,6 & 11,0 & 1,20 & & & 0,3 & & & & tr. & \\
\hline 42 & fib. elbow rep. & 71101 & bow & 83,2 & 11,0 & 3,30 & & & 0,8 & & & & & \\
\hline 43 & fib. elbow rep. & 71101 & bow & 83,5 & 12,0 & 3,10 & & & 0,7 & & & & & \\
\hline 44 & sword & 70627 & blade & 93,6 & 5,3 & 0,30 & & & 0,2 & & & & & \\
\hline 45 & sword & 70627 & point & 91,5 & 8,4 & tr. & & & 0,3 & & & & & \\
\hline 46 & sword & 70627 & sheet & 90,2 & 9,3 & - & tr. & & 0,7 & & & & tr. & \\
\hline
\end{tabular}

Table 1. Madonna del Piano - integrated XRF-, AAS- and SEM/EDS results (\% in weigth).

T. P., 67, N. ${ }^{\circ} 2$, julio-diciembre 2010, pp. 469-488, ISSN: 0082-5638

doi: $10.3989 /$ tp.2010.10051 


\begin{tabular}{|c|c|c|c|c|c|c|c|c|c|c|c|c|c|c|}
\hline Nr. & Object & $\begin{array}{l}\text { Nr. } \\
\text { Inv. }\end{array}$ & Part & $\mathrm{Cu}$ & Sn & $\mathbf{P b}$ & As & Sb & $\mathrm{Fe}$ & $\mathrm{Ni}$ & Co & Ag & $\mathbf{Z n}$ & Mn \\
\hline $46 b$ & sword & 70627 & sheet & 91,3 & 8,3 & - & tr. & & 0,5 & & & & & \\
\hline 47 & sword & 70627 & rivet & 89,7 & 9,7 & 0,30 & & & 0,5 & & & & & \\
\hline 48 & sword & 71146 & blade & 85,8 & 11,2 & 1,80 & tr. & & 0,7 & tr. & & tr. & & tr. \\
\hline 49 & sword & 71146 & point & 86,2 & 9,4 & 2,70 & 0,50 & tr. & 0,2 & & & tr. & & \\
\hline 50 & sword & 71146 & rivet 1 & 88,9 & 8,7 & 0,70 & & & 1,1 & tr. & & tr. & & \\
\hline 51 & sword & 71146 & rivet 2 & 90,4 & 8,5 & 0,40 & & & 0,5 & tr. & & & & \\
\hline 52 & sword & 71146 & rivet 3 & 90,6 & 8,5 & 0,50 & & & 0,5 & & & tr. & & \\
\hline 53 & sword & 71146 & rivet 1 & 98,5 & & tr. & & & 0,9 & & & tr. & tr. & \\
\hline 54 & sword & 71146 & rivet 2 & 98,8 & & tr. & & & 0,8 & & & & & \\
\hline 55 & sword & 71146 & sheet & 98,3 & & tr. & & & 1,2 & & & & & \\
\hline 56 & greave 1 & 70630 & & 88,4 & 10,3 & 0,80 & 0,30 & tr. & 0,2 & & & & & \\
\hline 57 & greave 2 & 70630 & & 87,1 & 10,6 & 1,20 & 0,40 & tr. & 0,4 & & & & & \\
\hline 58 & knife & 71353 & blade & 90,7 & 6,4 & 0,90 & & & 1,5 & tr. & & & & \\
\hline 59 & knife & 71353 & rivet 1 & 91,2 & 5,9 & 0,80 & & & 1,3 & & & & & \\
\hline 60 & knife & 71353 & rivet 2 & 91,4 & 6,1 & 0,80 & & & 0,9 & tr. & & & & tr. \\
\hline 61 & knife & 71353 & rivet 3 & 91,2 & 6,2 & 0,70 & & & 0,9 & & & & tr. & \\
\hline 62 & belt hook & 71354 & hook & 92,2 & 6,3 & 0,50 & & & 1,2 & & & & & \\
\hline 63 & knife & 71362 & blade & 89,3 & 8,2 & 1,60 & & & 0,5 & & & & & \\
\hline 64 & knife & 71362 & rivet 1 & 88,6 & 10,5 & & & & 0,4 & & & & & \\
\hline 65 & knife & 71362 & rivet 2 & 88,4 & 10,2 & & & & 0,5 & & & & & \\
\hline 66 & belt decor. & 71363 & cross & 78,3 & 17,0 & 0,80 & 0,50 & 0,40 & 0,4 & tr. & & & & \\
\hline 67 & belt decor. & 71363 & ring & 79,8 & 17,0 & 1,10 & 0,40 & 0,30 & 0,3 & tr. & & & & \\
\hline 68 & tintinnabulum & 71360 & tub. Large & 88,5 & 10,9 & & & & 0,5 & & & & & \\
\hline 69 & tintinnabulum & 71360 & tub. med. & 87,7 & 11,8 & tr. & & & 0,6 & & & & tr. & \\
\hline 70 & tintinnabulum & 71360 & tub. Small & 86,9 & 12,2 & & & & 0,3 & & & & & \\
\hline 71 & tintinnabulum & 71360 & tub. Small 2 & 88,2 & 11,6 & & & & 0,2 & & & & & \\
\hline 72 & tintinnabulum & 71362 & ring 1 & 85,3 & 13,2 & tr. & & & 0,7 & & tr. & & & tr. \\
\hline 73 & tintinnabulum & 71362 & ring 2 & 85,8 & 12,8 & tr. & & & 0,9 & & & tr. & & \\
\hline 74 & f. bow & 71144 & bow & 88,8 & 10,5 & 0,30 & tr. & $\operatorname{tr}$. & 0,6 & & & & & \\
\hline 75 & razor & 71145 & handle & 93,7 & 4,5 & & & & 0,8 & & & & tr. & \\
\hline 76 & f. elbow & 70606 & bow & 89,4 & 10,2 & tr. & tr. & & 0,3 & & & & & \\
\hline 77 & wire & 70605 & & 98,9 & & & 11. & & 0,9 & & & & & \\
\hline 78 & f. antennae & 71204 & catchplate & 88,7 & 10,0 & 0,20 & 0,20 & - & 0,1 & & & & tr. & \\
\hline 79 & f. antennae & 71204 & antennae & 88,2 & 9,2 & 1,20 & & & 0,4 & $\operatorname{tr}$. & & & & \\
\hline 80 & f. antennae & 71204 & bow & 89,6 & 11,0 & - & & & 0,2 & & & & & tr. \\
\hline 81 & f. antennae & 71204 & pin & 89,8 & 10,0 & & & & 0,1 & & & & & \\
\hline 82 & belt decor. & 71209 & int. circlet & 84,1 & 14,8 & tr. & tr. & tr. & 0,1 & & & tr. & & \\
\hline 83 & belt decor. & 71209 & ext. circlet & 83,4 & 15,0 & 0,70 & tr. & tr. & 0,1 & & & & & \\
\hline 84 & knife & 71208 & blade & 90,2 & 6,0 & 2,20 & & & 0,7 & & & & & \\
\hline 85 & knife & 71208 & rivet 1 & 88,9 & 8,0 & 1,10 & & & 1,5 & tr. & & & & \\
\hline 86 & knife & 71208 & rivet 2 & 89,3 & 7,5 & 0,90 & & & 1,3 & & & & & tr. \\
\hline 87 & knife & 71208 & rivet 3 & 89,2 & 8,0 & 1,10 & & & 0,9 & tr. & & & & \\
\hline 88 & reel & 71205 & & 85,4 & 7,3 & 4,20 & & & 0,4 & & & & & \\
\hline 89 & f. elbow & 71369 & catchplate & 87,1 & 11,2 & & tr. & tr. & 0,6 & & & & & \\
\hline 90 & f. elbow & 71369 & bow long & 88,2 & 10,0 & 0,60 & & & 0,8 & & & & & \\
\hline 91 & f. elbow & 71369 & bow short & 87,4 & 9,5 & 1,40 & tr. & tr. & 1 & & & & tr. & \\
\hline 92 & f. elbow & 71369 & & 87,9 & 11,0 & & & & 0,8 & & & & & \\
\hline 93 & f. 3 loops & 70961 & plaque & 92,3 & 4,2 & 0,80 & & & 0,3 & & & & tr. & \\
\hline 94 & f. 3 loops & 70961 & bow & 91,1 & 4,5 & 0,90 & & & 0,3 & & & & & \\
\hline 95 & knife & 71385 & blade & 91,6 & 5,2 & 2,10 & tr. & & 0,4 & & & & & \\
\hline 96 & reel & 71418 & head & 93,7 & 4,2 & 3,20 & & & 0,6 & tr. & & & & tr. \\
\hline 97 & reel & 71418 & centre & 90,2 & 4,5 & 4,00 & & & 0,3 & & & & & \\
\hline 98 & reel & 71406 & centre & 91,3 & 6,2 & 1,80 & & & 0,2 & & & & & \\
\hline 99 & tube & 71406 & & 92,4 & 5,2 & 0,60 & 0,03 & 0,01 & 0,5 & tr. & & & tr. & \\
\hline 100 & tintinnabulum & 71155 & barra & 91,7 & 7,2 & 0,30 & tr. & tr. & 0,4 & & & & & \\
\hline 101 & tintinnabulum & 71156 & tube 1 & 88,6 & 11,0 & & & & 0,3 & & & & & \\
\hline 102 & tintinnabulum & 71156 & tube 2 & 89,2 & 10,7 & & & & 0,3 & & & & & \\
\hline 103 & tintinnabulum & 71156 & tube 3 & 88,2 & 11,3 & & & & 0,2 & & & & & \\
\hline 104 & tintinnabulum & 71156 & tube 4 & 88,5 & 10,8 & & & & 0,1 & & & & & \\
\hline
\end{tabular}

Table 1. Madonna del Piano - integrated XRF-, AAS- and SEM/EDS results (\% in weigth) (continuación). 


\begin{tabular}{|c|c|c|c|c|c|c|c|c|c|c|c|c|c|c|}
\hline Nr. & Object & $\begin{array}{l}\text { Nr. } \\
\text { Inv. }\end{array}$ & Part & $\mathrm{Cu}$ & Sn & $\mathbf{P b}$ & As & Sb & $\mathrm{Fe}$ & $\mathbf{N i}$ & Co & Ag & $\mathrm{Zn}$ & Mn \\
\hline 105 & tintinnabulum & 71165 & toro & 85,3 & 10,2 & 3,50 & tr. & tr. & 0,2 & & & tr. & & \\
\hline 106 & tintinnabulum & 71161 & ring & 84,2 & 14,3 & tr. & & & 0,1 & & & & & \\
\hline 107 & tintinnabulum & 71161 & ring & 83,4 & 15,2 & tr. & & & 0,2 & & & & & \\
\hline 108 & tintinnabulum & 71161 & ring & 83,3 & 15,3 & tr. & & & 0,1 & & & & & \\
\hline 109 & tintinnabulum & 71161 & ring & 84,5 & 14,9 & tr. & & & 0,1 & & & & & \\
\hline 110 & tintinnabulum & 71161 & ring & 83,6 & 15,2 & tr. & & & 0,2 & & & & & \\
\hline 111 & tintinnabulum & 71161 & ring & 83,5 & 15,1 & & & & 0,1 & & & & tr. & \\
\hline 112 & tintinnabulum & 71161 & ring & 83,4 & 15,3 & tr. & & & 0,2 & & & & & \\
\hline 113 & anklet & 71377 & & 86,8 & 7,2 & 4,20 & & & 0,6 & tr. & & & & tr. \\
\hline 114 & anklet & 71377 & & 87,9 & 6,6 & 3,80 & & & 0,5 & & & & & \\
\hline 115 & f. bow & 71375 & bow & 88,2 & 6,0 & 5,00 & 0,03 & tr. & 0,2 & & tr. & & & \\
\hline 116 & f. Cassibile & 71395 & bow & 85,4 & 10,0 & 4,00 & & & - & & & & & \\
\hline 117 & f. Cassibile & 71395 & catchplate & 85,3 & 10,0 & 4,20 & & & - & & & & & \\
\hline 118 & f. bow rit. & 71136 & bow & 90,2 & 9,2 & 0,40 & & & & & & & tr. & \\
\hline 119 & f. bow dec. & 71135 & bow & 88,3 & 11,3 & tr. & & & 0,1 & tr. & & & & tr. \\
\hline 120 & knife & 71185 & blade & 93,8 & 5,2 & & tr. & & 0,2 & & & & & \\
\hline 121 & f. ribbon & 71389 & bow & 84,9 & 9,8 & 4,30 & & & 0,5 & & & & & \\
\hline
\end{tabular}

Table 1. Madonna del Piano - integrated XRF-, AAS- and SEM/EDS results ( $\%$ in weigth) (final). 